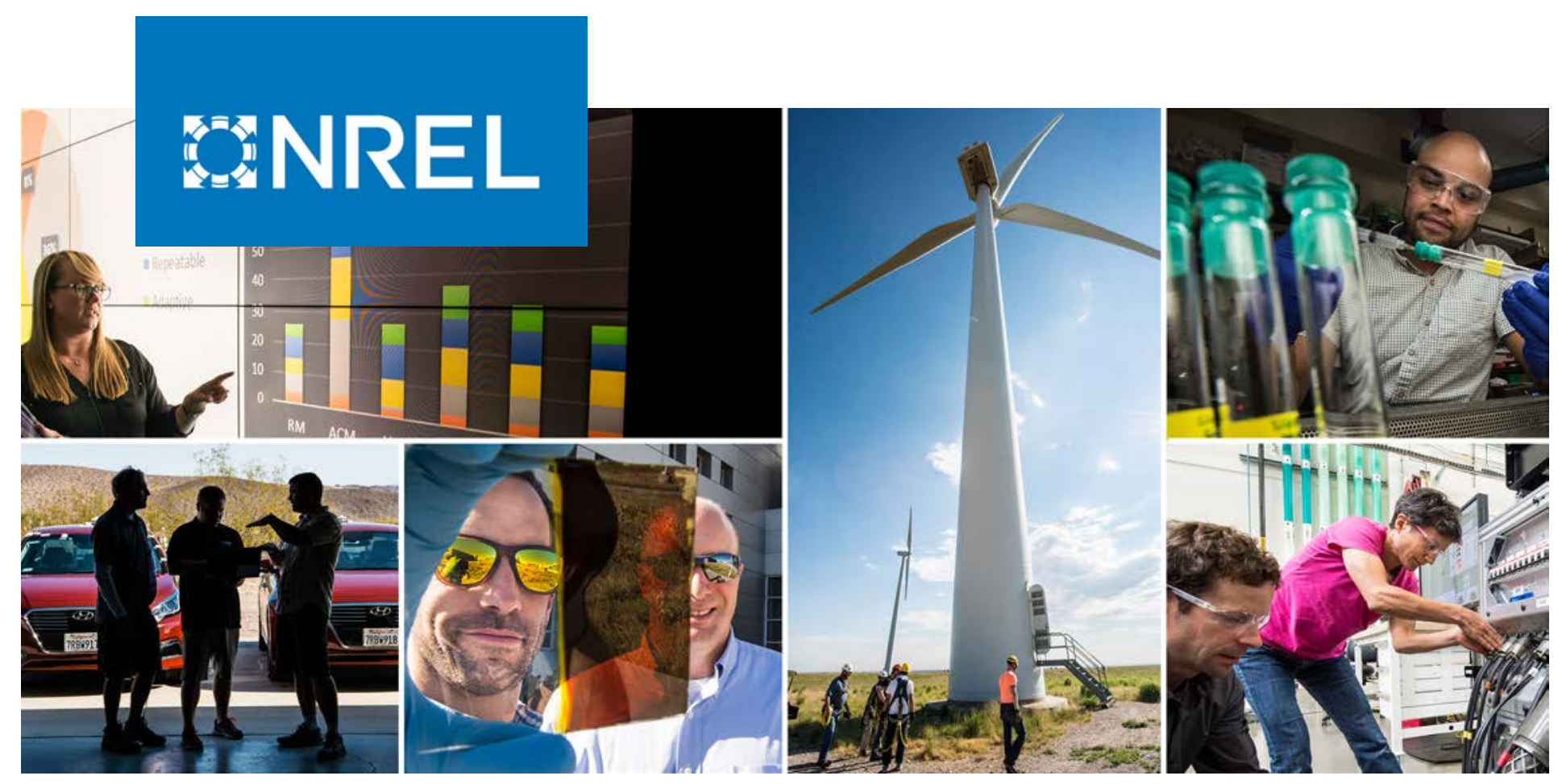

\title{
Distributed Solar Photovoltaic Cost- Benefit Framework Study: Considerations and Resources for Oklahoma
}

Alison Holm, Jeffrey J. Cook, Alexandra Aznar, Jason Coughlin, and Benjamin Mow

National Renewable Energy Laboratory

NREL is a national laboratory of the U.S. Department of Energy Office of Energy Efficiency \& Renewable Energy

Operated by the Alliance for Sustainable Energy, LLC

This report is available at no cost from the National Renewable Energy Laboratory (NREL) at www.nrel.gov/publications.
Technical Report

NREL/TP-7A40-72166

August 2019 


\title{
GNREL
}

\section{Distributed Solar Photovoltaic Cost- Benefit Framework Study: Considerations and Resources for Oklahoma}

\author{
Alison Holm, Jeffrey J. Cook, Alexandra Aznar, \\ Jason Coughlin, Benjamin Mow \\ National Renewable Energy Laboratory
}

\section{Suggested Citation}

Holm, Alison, Jeffrey J. Cook, Alexandra Aznar, Jason Coughlin, and Benjamin Mow. 2019. Distributed Solar Photovoltaic Cost-Benefit Framework Study: Considerations and Resources for Oklahoma. Golden, CO: National Renewable Energy Laboratory. NREL/TP-7A40-72166. https://www.nrel.gov/docs/fy19osti/72166.pdf.

NREL is a national laboratory of the U.S. Department of Energy Office of Energy Efficiency \& Renewable Energy Operated by the Alliance for Sustainable Energy, LLC

This report is available at no cost from the National Renewable Energy Laboratory (NREL) at www.nrel.gov/publications.

Contract No. DE-AC36-08GO28308
Technical Report NREL/TP-7A40-72166 August 2019

National Renewable Energy Laboratory 15013 Denver West Parkway Golden, CO 80401 303-275-3000 • www.nrel.gov 


\section{NOTICE}

This work was authored by the National Renewable Energy Laboratory, operated by Alliance for Sustainable Energy, LLC, for the U.S. Department of Energy (DOE) under Contract No. DE-AC36-08GO28308. Funding provided by U.S. Department of Energy Office of Energy Efficiency and Renewable Energy Solar Energy Technologies Office. The views expressed herein do not necessarily represent the views of the DOE or the U.S. Government.

This report is available at no cost from the National Renewable Energy Laboratory (NREL) at www.nrel.gov/publications.

U.S. Department of Energy (DOE) reports produced after 1991 and a growing number of pre-1991 documents are available free via www.OSTI.gov.

Cover Photos by Dennis Schroeder: (clockwise, left to right) NREL 51934, NREL 45897, NREL 42160, NREL 45891, NREL 48097, NREL 46526.

NREL prints on paper that contains recycled content. 


\section{Disclaimer}

This work was authored by the National Renewable Energy Laboratory (NREL), operated by Alliance for Sustainable Energy, LLC, for the U.S. Department of Energy (DOE) under Contract No. DE-AC36-08GO28308. Funding provided by the DOE Office of Energy Efficiency and Renewable Energy Solar Energy Technologies Office.

This report was developed under the Solar Technical Assistance Team (STAT) Network, a project funded by the DOE Solar Energy Technologies Office and implemented by NREL from 2016-2018. The STAT Network provided credible and timely information to policymakers and regulators for the purpose of solar technology and policy-related decision support. Through STAT, state and local decision makers could request on-demand analytical support on a range of solar technology-, finance-, and policy-related topics. This report is the result of a technical assistance request from the State of Oklahoma. The STAT Network program sunset in September 2018; a database of past projects is available online at https://www.nrel.gov/statelocal-tribal/project-map/index.html.

The Oklahoma Office of the Secretary of Energy and Environment (OSEE) requested information and resources on distributed energy generation cost-benefit analyses, and a methodology and decision framework for assessing the costs and benefits of distributed energy resources in the state. This baseline study on approaches to distributed solar photovoltaic (DPV) compensation and cost-benefit valuation mechanisms is the first part of a two-part effort. The goal of this report is to clarify the range of compensation structures used for DPV across the country and what factors are considered in each framework, including net energy metering and billing, value of solar (VOS), and other models. From this foundation, we then offer a summary of the variables that have been, or could be, considered in the development of a DPV cost-benefit valuation framework. The second part of this effort expands on the range of variables that could be used to develop a DPV valuation methodology and decision matrix and includes additional detail regarding potential approaches for quantifying the different variables.

This analysis was conducted to meet an immediate need and was based on the best information the analysts had available within time constraints. This report is intended to be a starting point for additional research and analysis into solar options for OSEE and does not constitute a comprehensive roadmap for solar deployment. This report was originally developed for and presented to OSEE in February 2018. The information was later published to make the contents publicly available for other entities considering similar questions. However, distributed solar compensation mechanisms and U.S. state approaches to quantifying the costs and benefits of distributed energy resources are evolving rapidly. The information presented here is current as of August 2018.

The views expressed in this report do not necessarily represent the views of the DOE or the U.S. Government. This document was prepared as an account of work sponsored by an agency of the United States government. Neither the United States government nor any agency thereof, nor any of their employees, makes any warranty, express or implied, or assumes any legal liability or responsibility for the accuracy, completeness, or usefulness of any information, apparatus, product, or process disclosed, or represents that its use would not infringe privately owned rights. 
Reference herein to any specific commercial product, process, or service by trade name, trademark, manufacturer, or otherwise does not necessarily constitute or imply its endorsement, recommendation, or favoring by the United States government or any agency thereof. The views and opinions of authors expressed herein do not necessarily state or reflect those of the United States government or any agency thereof. 


\section{Acknowledgments}

The authors would like to thank the Oklahoma Office of the Secretary of Energy and Environment (OSEE), particularly Secretary Michael Teague and Jeremy Bennett, for their engagement in this effort. The authors would also like to thank the members of the Oklahoma Distributed Generation Thought Group for their attentiveness, questions, and feedback on this project. This report benefited from questions, comments and input from a range of Oklahoma stakeholders, including representatives from OSEE, the Oklahoma Corporation Commission (Public Utility Division), the Office of the Attorney General of Oklahoma, Oklahoma Industrial Energy Consumers, the Oklahoma Sustainability Network, law firms Philips Murrah and Hall Estill, and several Oklahoma utilities, including Grand River Dam Authority, Oklahoma Association of Electric Cooperatives, Oklahoma Municipal Power Authority, Oklahoma Gas and Electric, Public Service Co. of Oklahoma/American Electric Power, and Western Farmers Electric Cooperative.

The authors would also like to thank NREL subject matter experts Elizabeth Doris, Karlynn Cory, Paul Denholm, and Robert Margolis for their input and direction in developing this work, and to Andrea Watson, Megan Day, and Adam Warren for providing helpful reviews on several drafts of this report. Thank you to external reviewers, including Nate Hausman at the Clean Energy States Alliance (CESA), and Nadav Enbar and Steven Coley at the Electric Power Research Institute (EPRI) for providing feedback and clarifying questions.

Finally, we wish to thank Shamara Collins and Kyle Fricker at DOE for their helpful edits and the DOE Solar Energy Technologies Office for their overall support of the Solar Technical Assistance Team project. 


\section{List of Acronyms}

DG

DOE

DPV

FIT

$\mathrm{kW}$

$\mathrm{kWh}$

MN DOC

MW

$\mathrm{mWh}$

NEM

NREL

OSEE

PUC

PV

SEIA

STAT

T\&D

VOS distributed generation

U.S. Department of Energy

distributed solar photovoltaic

feed-in tariff

kilowatt

kilowatt-hour

Minnesota Department of Commerce

megawatt

megawatt-hour

net energy metering

National Renewable Energy Laboratory

Oklahoma Office of the Secretary of Energy and Environment

Public Utility Commission

photovoltaic

Solar Energy Industries Association

Solar Technical Assistance Team

transmission and distribution

value of solar 


\section{Executive Summary}

The residential solar market, which comprises the bulk of the distributed solar photovoltaic (DPV) landscape in the United States, grew from 246 megawatts (MW) installed in 2010 to 2,602 MW installed in 2016 (Wood Mackenzie, Limited/SEIA 2017). However, this deployment has not been equally distributed throughout the nation, due in part to variations in the value proposition of DPV by location. Given the changing economics of DPV and its growth nationwide, many states are reviewing their DPV policy landscapes, including compensation structures. In the context of a rapidly evolving distributed energy sector, it is unclear if existing compensation structures fully address the range of costs and benefits - collectively the "net value" - of DPV. Quantifying these costs and benefits is challenging, and states have not adopted a standardized approach to determining a localized net DPV value.

This report highlights different state-level approaches to compensating DPV system owners for excess generation and discusses the different variables that are being, or could be, included in quantifying the costs and benefits associated with DPV. There are several existing approaches to operationalize cost-benefit values associated with DPV systems, including net energy metering (NEM), value of solar (VOS) tariffs, and rate design. ${ }^{1}$ This report concentrates on state approaches to metering and billing arrangements, which fall into three primary categories: net energy metering, net billing, and buy-all, sell-all arrangements. In some cases, states have adopted relatively simple compensation approaches by specifying that excess generation be compensated at an existing value, such as the avoided cost. ${ }^{2}$ In other cases, states have undertaken more involved stakeholder processes to identify rates and compensation values based on the net calculated costs and benefits of DPV.

Historically, states have used relatively simple proxy values (e.g., no compensation, avoided cost, wholesale rate, and retail rate) to determine a compensation value for electricity supplied by DPV systems; however, a DPV compensation value other than one of these requires some degree of negotiation and calculation. As DPV penetration levels are rising and costs are declining, states are exploring net energy metering successor policies, including net-billing and buy-all, sell-all approaches. ${ }^{3}$

There are multiple ways to quantify the costs and benefits of DPV in terms of net value to the utility, the electricity-generating customer, and the non-electricity generating customer. Outcomes of these calculations generally depend on location, time horizon, the relative degree of

\footnotetext{
${ }^{1}$ For a more thorough discussion of sell rate design, retail rate design, and visual schematics of the net energy metering and billing arrangements discussed here, refer to the 2017 NREL issue brief, Grid-Connected Distributed Generation: Compensation Mechanism Basics, available at https://www.nrel.gov/docs/fy18osti/68469.pdf.

${ }^{2}$ In this context, avoided costs refer to costs that a utility would otherwise incur to generate or procure the power or services being supplied by the DPV systems. Avoided cost rates vary by state. For a discussion of avoided costs, see https://www.nrel.gov/docs/fy10osti/47408.pdf.

${ }^{3}$ Net energy metering successor policies typically refer to those policies that are adopted to replace net energy metering at the full retail rate. These successor policies commonly include net-billing or buy-all, sell-all approaches, under which excess generation is compensated at either the avoided cost rate or some other value-based crediting.
} 
the importance decision makers place on the factors being measured, the cost of the analysis, and the complexity of methods used.

To date, no standard methodology exists to calculate DPV costs and benefits, but seven overarching sources (or categories) of costs and benefits are often considered (Denholm et al. 2014). These include:

- Energy: The energy category refers to the net costs and benefits derived from the actual electricity generation of the DPV system (in kilowatt-hours [kWh] or megawatt-hours [MWh]).

- Transmission and Distribution (T\&D) Losses: Electricity is lost in transit, and these losses are typically lower for DPV systems, due to their proximity to load. Factors such as displaced electricity losses at marginal power generators can be important in estimating the net costs and benefits provided by DPV.

- Generation Capacity: Customers' energy bills consist of not only energy charges for actual electricity consumed, but also fixed charges or costs. The ability of DPV to reduce the capital costs associated with building power plants and T\&D infrastructure is called its capacity value. Estimating the generation capacity value of DPV requires calculating the actual fraction of a DPV system's capacity that could reliably be used to offset conventional capacity.

- T\&D Capacity: DPV installations can affect both congestion and reliability in the transmission system and can decrease or increase distribution system capacity investments. A large enough concentration of DPV at one location can relieve the transmission network and reduce the need for additional transmission capacity; this may not always be true in terms of distribution capacity. DPV can offset investments required to maintain reliability, or accommodate growth in certain load pockets, given the local generation can be used to offset local grid needs. But high local penetrations of DPV may require upgrading wires, transformers, and voltage-regulation devices that could offset some or all of the aforementioned benefits.

- Environmental Costs and Benefits: A variety of environmental factors can be considered when assessing net DPV costs and benefits, such as avoided emissions, reductions in criteria pollutants, water consumption, and land impacts, or avoided renewable portfolio standard compliance costs.

- Ancillary Services: Ancillary services represent a broad set of grid-related costs and benefits that DPV systems may provide, such as voltage control and operating reserves.

- Other: A range of other factors, such as fuel price hedging or market-price suppression, could also be considered as potential costs and benefits in evaluating the net cost-benefit value of DPV generation.

States have taken different approaches to determine which variables to include and how to calculate the costs and benefits of each to determine a net DPV value. This report explores a range of VOS tariffs and studies commissioned across the United States and discusses the variables considered and the cost-benefit frameworks employed.

How these variables are evaluated will depend on several factors, including the stakeholder perspective, time frame assessed, and locational siting considerations. For example, in the shortterm, the net value associated with deferring T\&D capacity may be minimal, whereas this value 
would be higher in the longer term. Thus, the time frame lens through which solar compensation variables are considered is critical. The cost-benefit calculation itself may also change over time, as the general characteristics of the electric system change. Therefore, it is important to update the analysis regularly — at least annually, if not more frequently ${ }^{4}$ - to reflect the evolving utility system. Locational considerations in siting, such as where DPV systems could contribute to deferring distribution system upgrades or reducing grid congestion, can also influence DPV costbenefit valuation. DPV costs and benefits may vary at different physical locations on the electric grid.

The relative emphasis placed on the DPV cost-benefit variables discussed above often vary based on the stakeholder group evaluating them. Four key stakeholders in DPV compensation discussions include the DPV system owner, other utility ratepayers, the utility, and policymakers representing society at large (see Table ES- 1).

Table ES- 1. Distributed Solar PV Perspectives

\begin{tabular}{ll}
\hline Stakeholder Perspective & Factors Affecting Value \\
\hline DPV system owner & $\begin{array}{l}\text { Benefits: Reduced utility bill, utility or state incentives, federal tax } \\
\text { credits, consumer empowerment } \\
\text { Costs: Distributed generation (DG) system capital cost }\end{array}$ \\
$\begin{array}{ll}\text { Other utility customers } \\
\text { (i.e., ratepayers) }\end{array}$ & $\begin{array}{l}\text { Benefits: Potential reduction in transmission, distribution, and generation } \\
\text { costs; ability to capture capacity benefits; ability to capture energy } \\
\text { benefits; and reduction of grid support services (depending on levels of } \\
\text { DPV deployment) } \\
\text { Costs: Administrative costs, cost of rebates/incentives }\end{array}$ \\
\hline $\begin{array}{l}\text { Utility operators } \\
\text { Benefits: Reduction in capacity costs, energy costs, and grid support } \\
\text { services } \\
\text { Costs: Administrative costs, cost of rebates/incentives, decreased } \\
\text { revenue, integration and interconnection costs }\end{array}$ \\
$\begin{array}{l}\text { Policymakers, society } \\
\text { Sum of the benefits and costs to all stakeholders, plus additional societal } \\
\text { and environmental costs and benefits that accrue to society at large } \\
\text { rather than any individual stakeholder. }\end{array}$ \\
\hline
\end{tabular}

Ultimately, there are many factors to consider when quantifying the net cost-benefit value of DPV to the electrical grid. At the same time, there are a wide variety of methodologies to quantify the benefits and costs. Individual jurisdictions will need to consider which terms are most relevant for evaluation, and their pertinence and applicability in distinct contexts. The DPV market, related services, and energy markets more broadly are rapidly evolving, so any effort to quantify the net cost-benefit value of DPV to the utility system should be an iterative and ongoing process.

\footnotetext{
${ }^{4}$ Sometimes annual updates are applied to all customers and sometimes just to new participants.
} 


\section{Table of Contents}

1 Overview of U.S. Distributed Solar Photovoltaics Market............................................................ 1

2 State Approaches to DG Valuation and Compensation ......................................................... 4

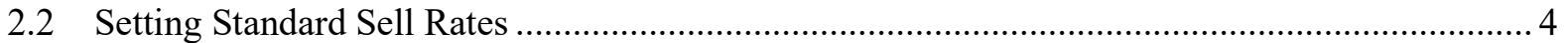

2.3 Evolution of State Approaches to Distributed Solar Compensation ............................................ 6

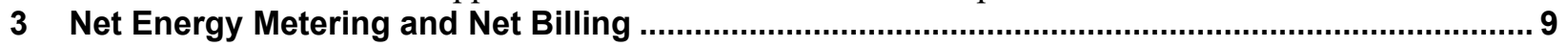

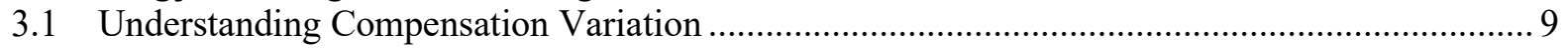

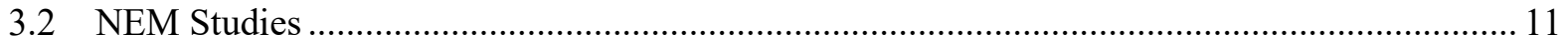

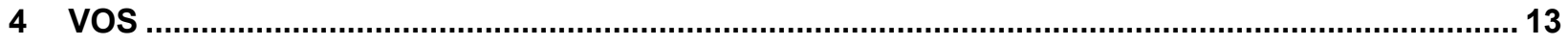

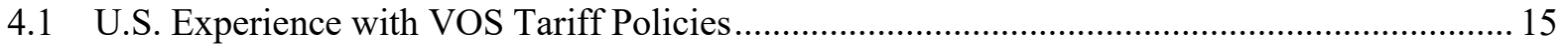

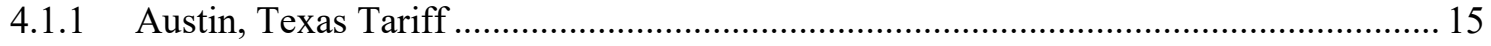

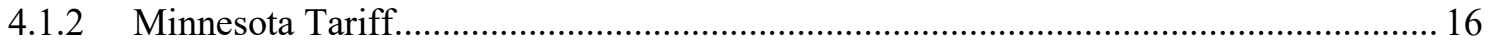

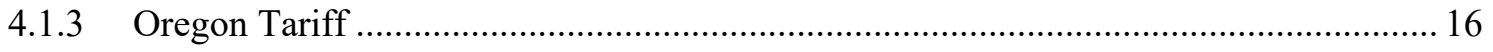

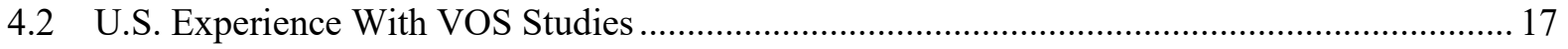

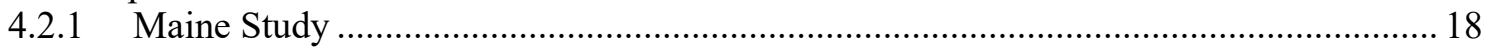

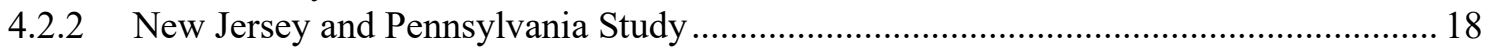

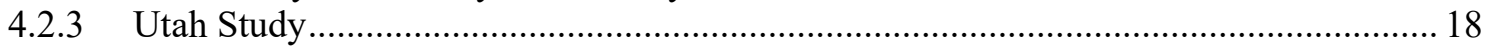

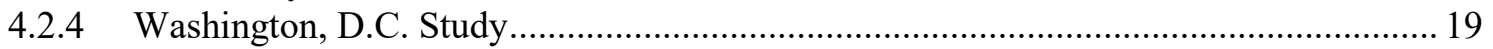

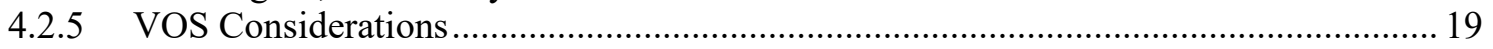

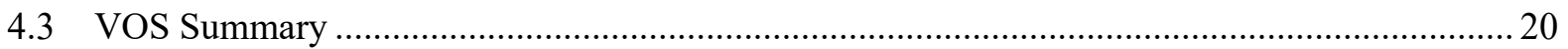

5 Variables Considered in Solar Net Cost-Benefit Valuation and Compensation ......................... 21

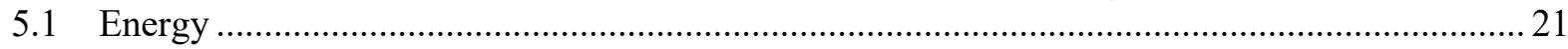

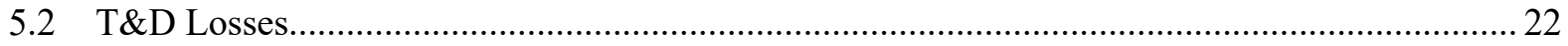

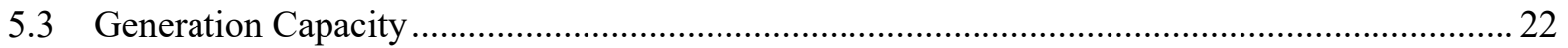

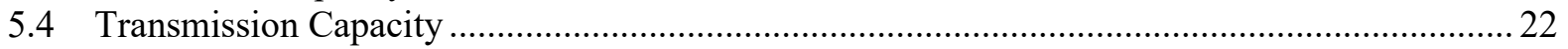

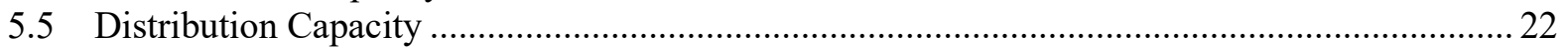

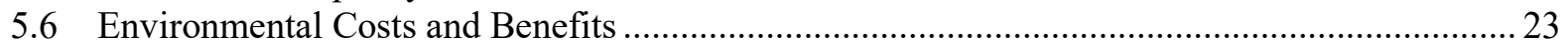

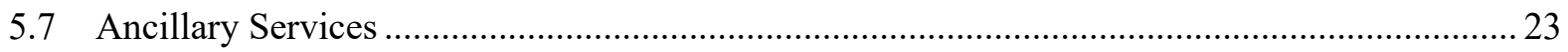

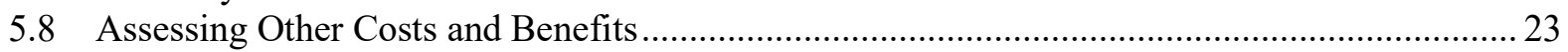

6 Compensation-Related Considerations for Key Stakeholders .................................................... 24

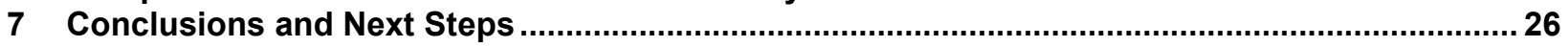

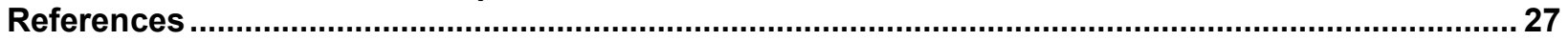

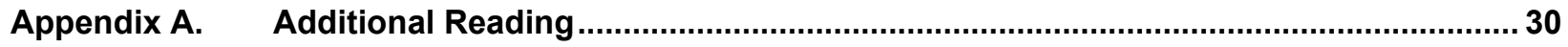

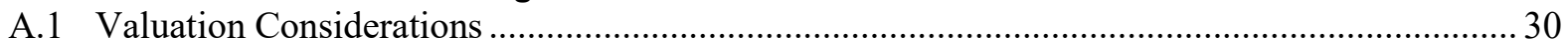

A.2 Next Generation Considerations: Distributed Solar Plus Storage ......................................... 31

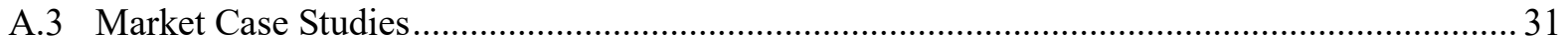

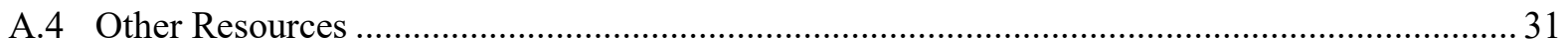




\section{List of Figures}

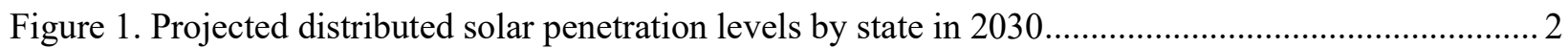

Figure 2. Theoretical visualization of solar valuation concept ........................................................... 6

Figure 3. Map of U.S. distributed solar photovoltaic compensation mechanisms ..................................... 7

Figure 4. Map of U.S. states conducting or initiating NEM and VOS studies ........................................ 8

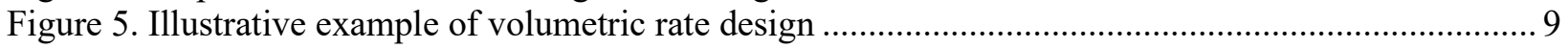

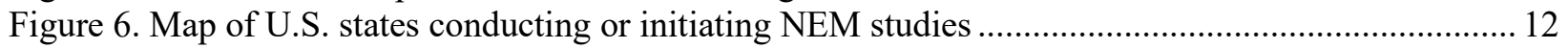

Figure 7. Austin Energy's annual VOS tariff rate schedule, 2012-2018 ............................................... 15

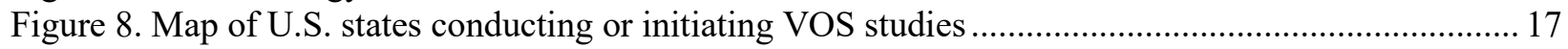

Figure 9. Comparison of VOS values to local retail electricity rates...................................................... 19

\section{List of Tables}

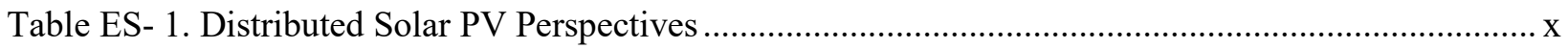

Table 1. Sample State Net Energy Metering and Net Billing Compensation Structures.......................... 10

Table 2. Factors Considered in Determining VOS Value in Selected Jurisdictions ................................. 14

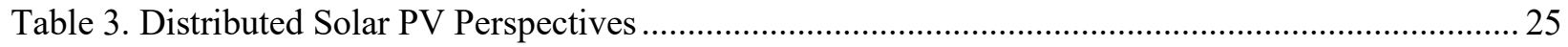




\section{Overview of U.S. Distributed Solar Photovoltaics Market}

Across the United States, the cumulative installed capacity of distributed solar photovoltaic (DPV) systems has been increasing year over year. The residential solar market, which comprises the bulk of the DPV landscape, grew from 246 megawatts (MW) installed in 2010 to 2,602 MW installed in 2016 (Wood Mackenzie, Limited/SEIA 2017). However, this deployment has not been equally distributed throughout the nation, due in part to variations in the value proposition of DPV by location. This economic disparity stems from a range of factors, including local electricity prices, but is also closely tied to state energy policies - some states have intentionally adopted DPV policies to enable more deployment (Steward and Doris 2014).

Given the changing economics of DPV and its growth nationwide, many states are reviewing their DPV policy landscapes, including compensation structures such as net energy metering (NEM). In the context of a rapidly evolving distributed energy sector, it is unclear if existing compensation structures fully address the range of costs and benefits - collectively the "net costbenefit value" - of DPV. Quantifying these costs and benefits is challenging, and states have not adopted a standardized approach to determining a localized net cost-benefit DPV value. Though some variation in DPV is expected given solar irradiance, market, and technology differences, states may benefit from the development of a common framework for evaluating DPV costs and benefits.

Based on data for calendar year 2016, small PV systems ${ }^{5}$ account for approximately $1.17 \%$ of the total electricity generating capacity in the United States (EIA 2017). By one estimate, DPV capacity is expected to represent as much as 4\% by 2030 (Barbose 2017). Yet, as noted above, this growth is not likely to be uniform. Based on current policy assumptions, the National Renewable Energy Laboratory (NREL) and Lawrence Berkeley National Laboratory (LBNL) project that less than half of U.S. states will exceed 1\% DPV deployment as a percentage of retail electricity sales by 2030, while some states will exceed 10\% (Barbose 2017; Cole et al. 2016) (see Figure 1).

\footnotetext{
${ }^{5}$ The U.S. Energy Information Administration (EIA) defines small PV systems as those with a generating capacity of less than $1 \mathrm{MW}$.
} 


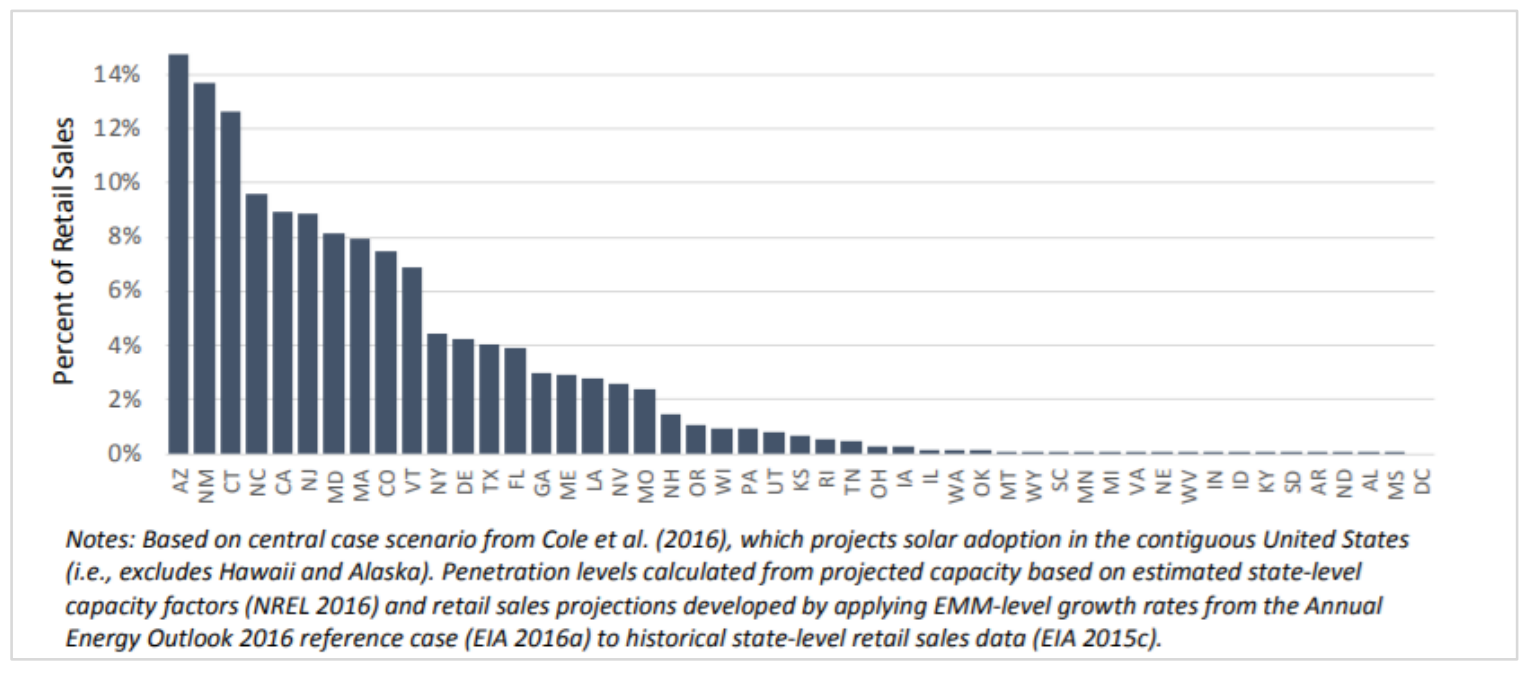

Figure 1. Projected distributed solar penetration levels by state in 2030

Source: Barbose 2017

DPV systems lack a standard definition, but are characterized by being relatively small (e.g., non-utility-scale), behind-the-meter, connected at the distribution system level, and dispersed across a given geographic area. Several other factors distinguish distributed generation (DG) from centralized electricity generating units, and these differences contribute to ongoing discussions about how the costs and benefits from electricity generated from DG systems should be assessed within the broader energy sector. Some of these factors include:

- DG systems are typically owned and operated by a home or business owner, as opposed to a utility or independent power producer;

- Power generation occurs at or near the point of consumption;

- DG systems produce two-way power flow (i.e., a customer can act as a producer and consumer of electricity); and

- From a utility perspective, there is limited visibility and control of DPV systems, because they are located behind customers' meters (although some utilities are beginning to require DPV production meters, even at the household level).

These DG characteristics provide unique benefits and challenges to power system planning, operation, and regulation. In addition to the distributed nature of these systems, DPV-like utility-scale wind and solar projects - produce variable electrical output, do not require fuel to operate, and do not directly produce emissions.

A spectrum of factors can influence DPV adoption, including policies that address DPV valuation and compensation. The terms "valuation" and "compensation" are often used interchangeably in discussions surrounding DPV systems and the electricity they export to the grid. The terms are closely related. For this report, we use compensation to refer to the actual dollar amount at which DPV system owners are compensated for electricity exported to the grid, and we use valuation to refer to the net costs and benefits, or inputs, that are considered and quantified in calculating a compensation level. 
Though not the central focus of this report, rate design is also part of the valuation equation. States have historically designed volumetric electricity rates, where electricity costs increase with consumption. As rate design becomes increasingly sophisticated, many states and utilities have also adopted peak and off-peak rate structures. Some states are establishing variable rates that account for the real-time and locational cost of electricity consumption. Newer rate models leveraging technological advances to more accurately distribute costs to users are resulting in a patchwork of rate design innovation across the United States. Updated approaches to rate design aim to ensure electricity rates more accurately reflect the actual cost of electricity at the time and place of consumption. Changes in rate design can influence DPV net cost-benefit value, particularly efforts to establish time-of-use rates, fixed charges, or demand charges for DPV customers. To the extent that these rate design elements overlap with existing DPV compensation mechanisms, they are discussed in more detail below. To date, production from DPV systems has most commonly been compensated through NEM, and, to a lesser extent in the United States, value of solar (VOS) and feed-in tariff (FIT) mechanisms. Methods for assessing the relative costs and benefits of DPV (i.e., solar valuation) are the core focus of this report. 


\section{State Approaches to DG Valuation and Compensation}

There are several approaches to compensating net excess generation from DPV systems, including NEM and net-billing arrangements and rate design. ${ }^{6}$ This report concentrates on state approaches to metering and billing arrangements, which fall into three primary categories:

- Net energy metering: Under NEM policies (often simply referred to as "net metering"), a DPV customer exports excess electricity that is not consumed on-site to the utility grid. The customer receives bill credits from the utility for that excess generation on a per kilowatt-hour $(\mathrm{kWh})$ basis. There are several variants across NEM policies, including the time frame under which customers can roll over their credits to offset subsequent bills (referred to as rollover options). From a billing standpoint, NEM is typically the most straightforward approach to DPV compensation because it provides a simple default compensation value - the local retail electricity rate.

- Net billing ${ }^{7}$ : Under a net billing arrangement, DPV customers consume the generated electricity on-site and export any excess generation to the utility grid - similar to NEMbut the excess generation is compensated at a predetermined sell rate rather than the full retail rate (see Section 2.2 on "Setting Standard Sell Rates"). Because excess generation is credited at a rate other than retail, net exports and net consumption are tracked in real time and are credited and billed separately.

- Buy-all, sell-all: Under a buy-all, sell-all arrangement, a DPV customer is compensated at a standard sell rate (see Section 2.1) for all the electricity their DPV system generates. All electricity is exported to the utility grid, as opposed to being consumed on-site. The DPV customer also purchases all electricity consumed at the standard retail rate as any other customer would, independent of the DPV system. Separate meters are deployed to facilitate buy-all, sell-all arrangements: one measuring the electricity imported from the grid and a second one to measure electricity produced by the PV system and exported to the grid.

\subsection{Setting Standard Sell Rates}

Unlike NEM, which uses the established local retail electricity rate as a compensation value for DPV, net billing and buy-all, sell-all approaches do not offer a standardized compensation amount for DPV electricity exported to the grid. Under net billing and buy-all, sell-all schemes, states have taken different approaches to establishing a sell rate (e.g., the compensation value for exported DPV electricity). In some cases, states have adopted relatively simple compensation approaches by specifying that excess generation be compensated at an existing rate, such as the

\footnotetext{
${ }^{6}$ For a more thorough discussion of sell and retail rate design and visual schematics of the NEM and billing arrangements discussed here, refer to the 2017 NREL issue brief, Grid-Connected Distributed Generation: Compensation Mechanism Basics, available at https:/www.nrel.gov/docs/fy18osti/68469.pdf.

${ }^{7}$ Net billing arrangements are sometimes referred to as non-retail-rate NEM. For clarity, this report refers to all retail rate compensation for excess DPV generation as NEM and all non-retail rate compensation for excess DPV generation as net billing.
} 
avoided cost rate. ${ }^{8}$ In other cases, states have undertaken more involved stakeholder processes to identify rates based on the net calculated costs and benefits of DPV.

One of the initial, fundamental tradeoffs among approaches is simplicity versus accuracy. On the spectrum of potential DPV valuation approaches, some states have opted for relatively simple, predetermined compensation rates - e.g., full retail rate NEM or net billing at the avoided cost rate - which are comparatively easy and fast to implement, but do not necessarily address specific costs and benefits associated with DPV. Others have combined different components to arrive at a net compensation rate; for example, pairing additional fixed costs for DPV customers with net billing compensation at the avoided cost rate. Still others have undertaken more complex efforts to quantify the specific costs and benefits associated with DPV; for example, by taking different environmental costs and benefits, deferred transmission and distribution (T\&D) infrastructure investments, and other factors, into consideration in developing a VOS methodology. ${ }^{9}$

The key takeaway is that there are certain known costs and benefits that can be incorporated into a solar valuation analysis (e.g., no compensation, avoided cost rate, wholesale rate, and retail rate), but a DPV compensation rate other than one of these requires some degree of negotiation or calculation. Figure 2 outlines a theoretical visualization of this concept.

The variables that could be considered in formulating a negotiated or calculated rate scenario are discussed in subsequent sections.

\footnotetext{
${ }^{8}$ In this context, avoided costs refer to costs that a utility would otherwise incur to generate or procure the power or services being supplied by the DPV systems. Avoided cost rates vary by state. For discussion of avoided costs, see https://www.nrel.gov/docs/fy10osti/47408.pdf.

${ }^{9}$ In the past, FITs were a common buy-all, sell-all compensation mechanism for DPV, particularly in Europe, though the FIT approach is less commonly adopted today. FITs represented a top-down method of DPV valuation in which policymakers essentially back-in to a DPV compensation value calculated based on the desired rate of return and payback period of a PV system to the system owner. Conversely, a VOS methodology is a bottom-up approach to building a compensation value based on the evaluation of numerous cost and benefit variables.
} 


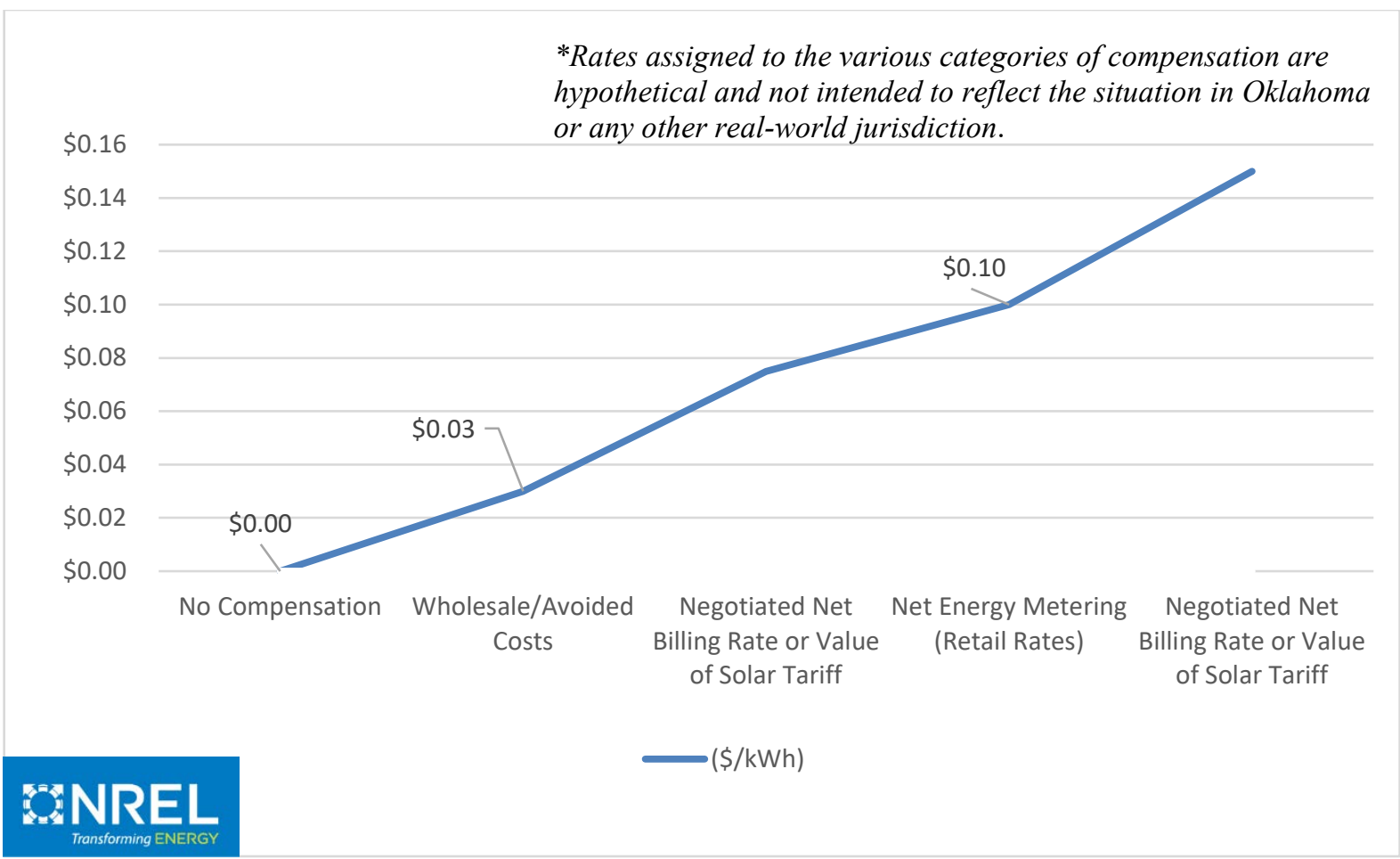

Figure 2. Theoretical visualization of solar valuation concept

All numbers are hypothetical

Source: NREL

\subsection{Evolution of State Approaches to Distributed Solar Compensation}

Net energy metering was a simple approach to compensate DPV system owners for excess generation when DPV applications were relatively new and expensive. Now, as DPV penetration levels are rising and costs are declining, states are exploring NEM successor policies, including net billing and buy-all, sell-all approaches. ${ }^{10}$ The catalysts for these changes vary, but are often driven by states reaching previously-determined caps on the amount of DPV generation allowed under NEM policies. As the DPV market context today is different than it was a decade ago, states that have reached DPV caps are now considering whether NEM is still an appropriate policy within the new market context.

Despite market changes and the dialogue surrounding DPV valuation, NEM policies represent the most common DPV compensation mechanism in the United States; however, the underlying motivations for implementing NEM policies (discussed in more detail in Section 3) have varied across states, as evidenced by differences in the specific policy parameters and implementation approaches. As of January 2018, 31 states, plus Washington, D.C., had implemented NEM policies and 14 had net-billing policies (DSIRE 2018; Proudlove et al. 2018) (see Figure 3). Net energy metering successor policies have been enacted in at least 10 states, including Arizona,

\footnotetext{
${ }^{10}$ Net energy metering successor policies typically refer to those policies that are adopted to replace NEM at the full retail rate. These successor policies commonly include net-billing or buy-all, sell-all approaches, under which excess generation is compensated at either the avoided cost rate or some other value-based crediting.
} 
California, Hawaii, Indiana, Maine, Nevada, New Hampshire, New York, Utah, and Vermont (Proudlove et al. 2018).

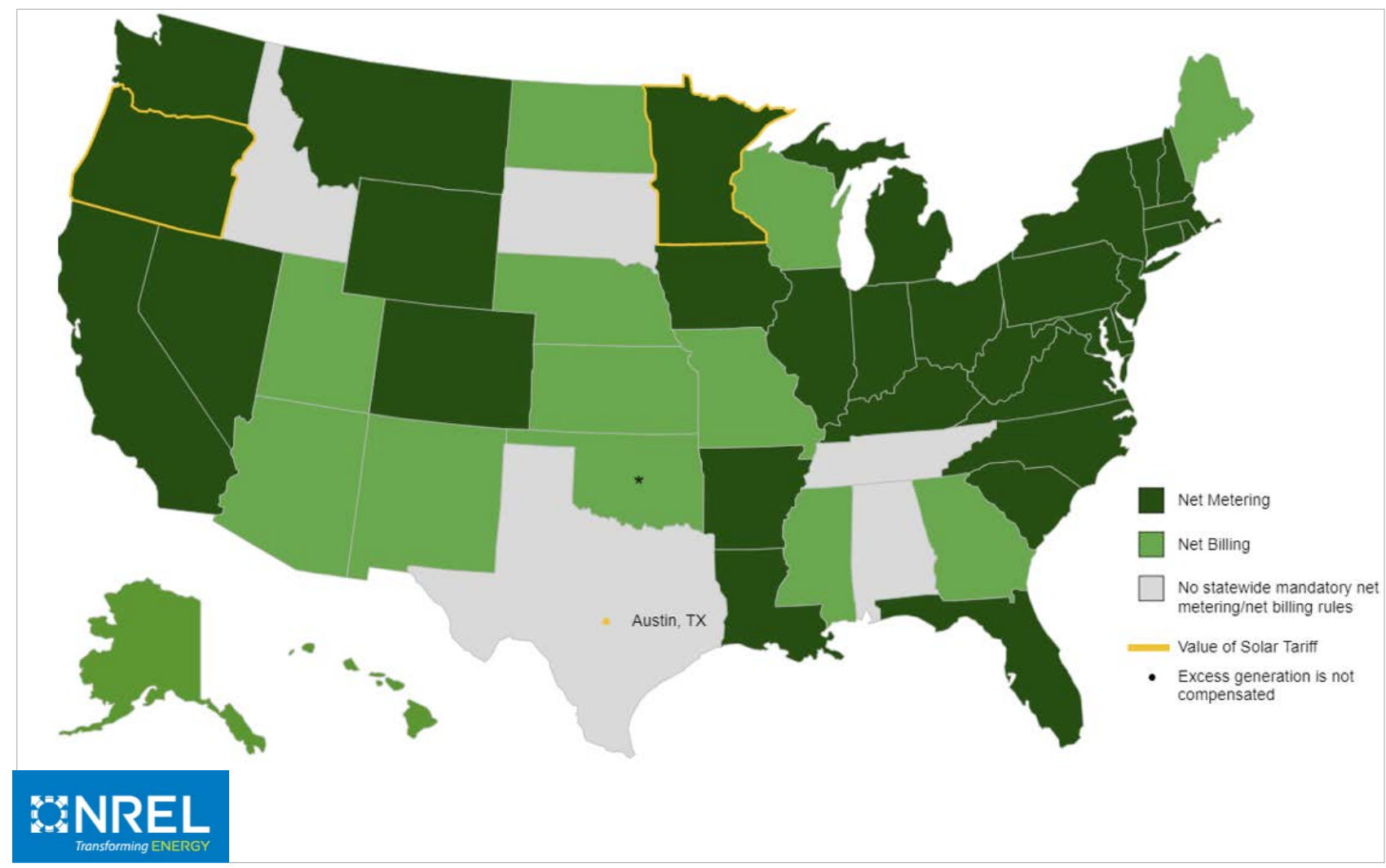

Figure 3. Map of U.S. distributed solar photovoltaic compensation mechanisms ${ }^{11}$

Sources: DSIRE; Proudlove 2018; NREL

To illustrate the dynamic nature of the policy environment, in calendar year 2017 alone, 31 states plus Washington, D.C., either considered or approved changes to their NEM policies (Proudlove et al. 2018), and at least 25 states have commissioned studies on the costs and benefits of renewable energy or DPV specifically. Figure 4 below highlights states that have either conducted or initiated studies on NEM, VOS, or both. ${ }^{12}$ While many states are active in the area of compensation issues and rate design, this map specifically highlights NEM and VOS studies.

\footnotetext{
${ }^{11}$ Map includes implemented policies only. As noted in the preceding text, several states have taken recent action on NEM successor policies, not all of which have been implemented to date.

12 The Solar Energy Industries Association (SEIA) maintains a database of DG cost-benefit studies commissioned by state, available at https://www.seia.org/initiatives/solar-cost-benefit-studies.
} 


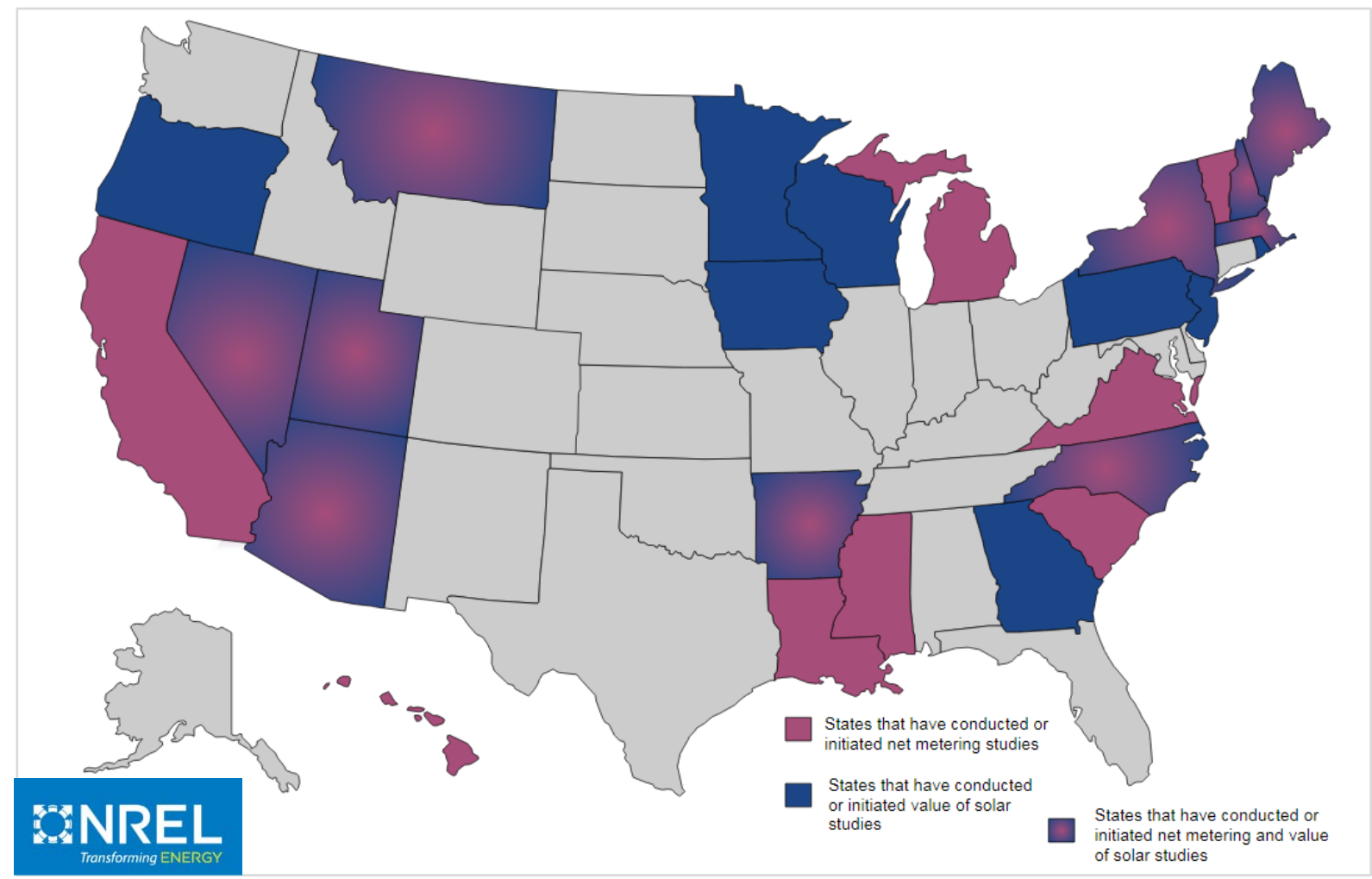

Figure 4. Map of U.S. states conducting or initiating NEM and VOS studies

Source: SEIA; Proudlove 2018; NREL

The policy discussions around compensation represent a broader market need to quantify the costs and benefits that DPV resources provide to the electrical grid and fairly compensate producers for that generation while minimizing rate impacts for non-solar customers. Devising these compensation structures has proven to be a balancing act between the priorities of different stakeholders, such as policymakers, utilities, ratepayers, and DPV system owners. These stakeholders often have different perspectives on what costs and benefits are most important or should be considered. For example, policymakers may be most interested in the overall impact of DPV compensation schemes on all ratepayers. In comparison, utilities may be most concerned about recouping investments from fixed capital projects, such as transmission infrastructure, while DPV system owners may be interested in reducing their energy costs (these perspectives are discussed in more detail in Section 6). Non-solar ratepayers are also interested in maintaining low and stable electricity rates.

DPV compensation policies are continually being reworked across the United States, and policy approaches are undergoing rapid evolution. To stay informed on these developments, SEIA maintains a database of state-level DPV cost-benefit studies. ${ }^{13}$ Additionally, the North Carolina Clean Energy Technology Center tracks state-level solar policy developments and publishes quarterly update reports. ${ }^{14}$

\footnotetext{
13 The SEIA database of state-level DPV cost-benefit studies is available at https://www.seia.org/initiatives/solarcost-benefit-studies.

14 The North Carolina Clean Energy Technology Center state-level solar policy development quarterly reports are available at https://nccleantech.ncsu.edu/the-50-states-reports/.
} 


\section{Net Energy Metering and Net Billing}

Net energy metering programs constitute the most common DPV compensation structure across the country, compensating DPV system owners for net excess generation at the retail electricity rate. The full retail electricity rate reflects the total cost of providing electricity to a customer, including transmission, distribution, and energy production. Most utility residential rate structures are designed volumetrically, where a customer's bill is based on how much electricity they use. As a result, utilities incorporate the cost of energy production and most fixed grid charges into a single, cents-per-kWh $(\$ / \mathrm{kWh})$ rate (see Figure 5).

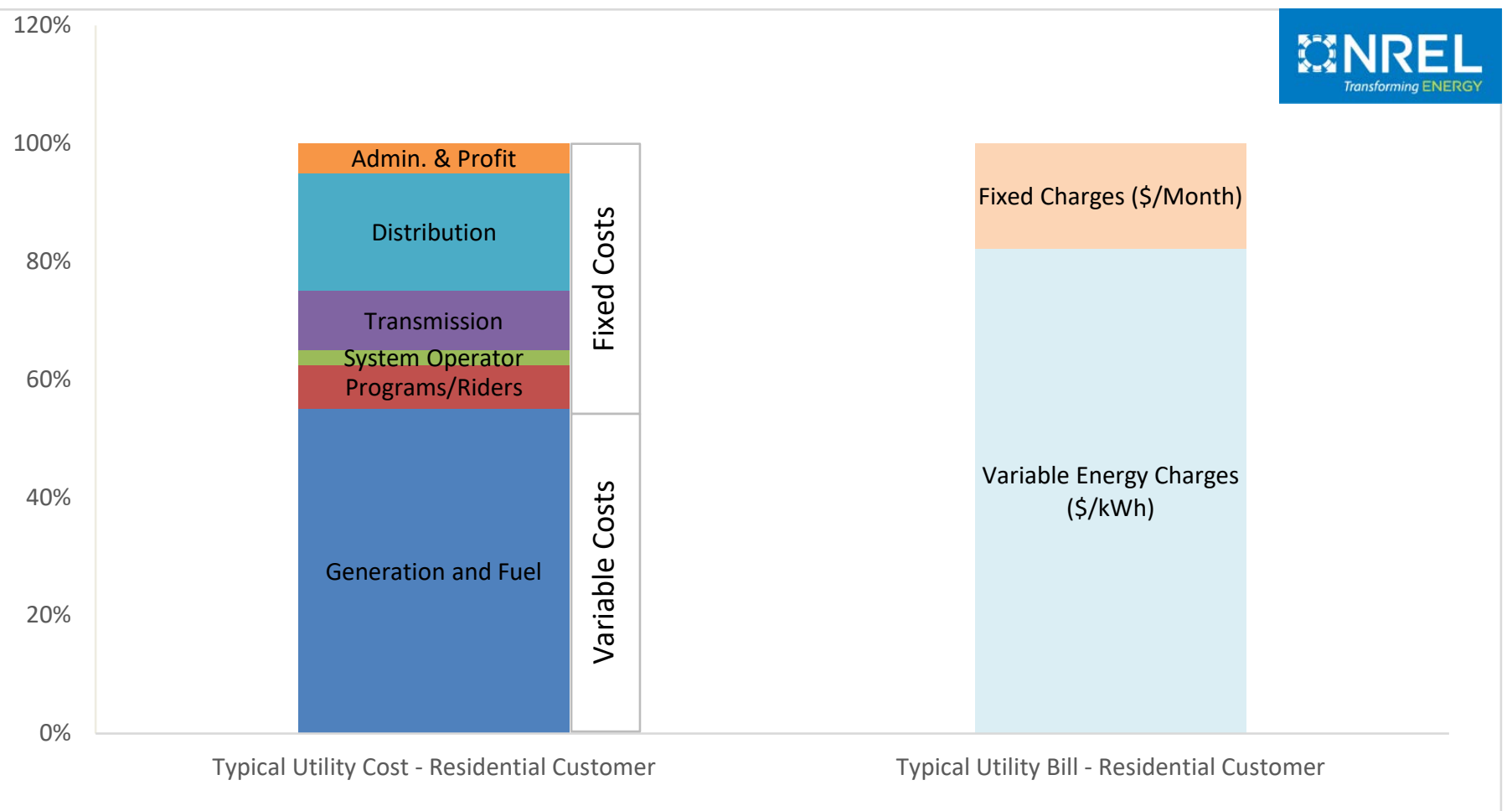

Figure 5. Illustrative example of volumetric rate design

Source: NREL

When residential customers use less energy, they generally pay less for all utility services; however, utilities are permitted by regulators to adopt certain fixed charges that apply, regardless of the electricity consumed. These fixed charges are typically used to recoup utility investments for meters and billing system software, among other functions. In some cases, utilities have also been allowed to incorporate higher fixed charges for certain DPV customers. These charges are used to offset grid integration costs and, in some cases, to recoup T\&D costs. If these fixed charges are imposed, it can reduce the overall value proposition for DPV customers and their investment in a PV installation.

\subsection{Understanding Compensation Variation}

To provide some perspective regarding variability in how NEM and net-billing arrangements are implemented, we explore approaches taken in four states: Arizona, North Dakota, Massachusetts, and Oregon. These states represent a range in DPV compensation structures and were selected to 
capture geographic diversity, differing statewide DPV penetration levels, and to specifically highlight variations across program type, excess generation rates, rollover options, and fixed PV charges. Key differences among these states' NEM and net billing structures are summarized in Table 1 and described in more detail below.

Table 1. Sample State Net Energy Metering and Net Billing Compensation Structures

\begin{tabular}{|c|c|c|c|c|}
\hline $\begin{array}{l}\text { Compensation } \\
\text { Variable }\end{array}$ & Arizona & North Dakota & Massachusetts & Oregon \\
\hline \multirow[t]{2}{*}{ Program Type } & \multirow[t]{2}{*}{ Net Billing } & \multirow[t]{2}{*}{ Net Billing } & $\begin{array}{l}\text { Net Energy Metering } \\
\text { (for residential) }\end{array}$ & \multirow[t]{2}{*}{$\begin{array}{l}\text { Net Energy } \\
\text { Metering }\end{array}$} \\
\hline & & & $\begin{array}{l}\text { Net Billing (for } \\
\text { commercial) }\end{array}$ & \\
\hline \multirow{2}{*}{$\begin{array}{l}\text { Excess } \\
\text { Generation Rate }\end{array}$} & \multirow[t]{2}{*}{ Avoided Cost } & \multirow[t]{2}{*}{ Avoided Cost } & $<1 \mathrm{MW}$ : Full Retail Rate & \multirow{2}{*}{$\begin{array}{l}\text { Full Retail } \\
\text { Rate }\end{array}$} \\
\hline & & & $\begin{array}{l}1-2 \mathrm{MW}: 60 \% \text { of the } \\
\text { Full Retail Rate }\end{array}$ & \\
\hline $\begin{array}{l}\text { Rollover } \\
\text { Options }\end{array}$ & $\begin{array}{l}\text { No option to } \\
\text { roll over } \\
\text { credits }\end{array}$ & $\begin{array}{l}\text { No option to roll over } \\
\text { credits }\end{array}$ & Indefinite rollover & $\begin{array}{l}\text { Credits roll } \\
\text { over for } 12 \\
\text { months, then } \\
\text { paid at } \\
\text { avoided cost }\end{array}$ \\
\hline $\begin{array}{l}\text { Fixed Charge } \\
\text { Specific to PV }\end{array}$ & Included & Not applicable & $\begin{array}{l}\text { Can be adopted once } \\
\text { the state's capacity } \\
\text { threshold is reached }\end{array}$ & Not applicable \\
\hline
\end{tabular}

Recently, Arizona changed its compensation structure from retail NEM to net energy billing, which includes a monthly fixed charge for DPV and compensates excess solar generation on a separate export tariff. ${ }^{15}$ This export rate is calculated from the utility's avoided electricity cost and is based on a proxy derived from a rolling average of utility-scale power purchase agreement rates. There is no opportunity to roll over export credits to offset future grid consumption.

North Dakota has a net billing program, with a compensation structure similar to Arizona's. Excess generation from DPV systems is compensated at the electric utility's avoided cost of electricity rate. ${ }^{16}$ In this case, the avoided cost is not tailored to PV; electricity generated from DPV systems is compensated at the same level offered to qualifying facilities under the Public Utility Regulatory Policies Act. There is also no option to roll over credits to offset future electricity demand.

In comparison, Massachusetts offers a NEM program for residential systems and a net billing program for commercial systems. In this case, net excess generation is credited at varying rates depending on the size of the DPV system. For PV projects less than $1 \mathrm{MW}$ in size (which includes residential DPV systems), excess generation is compensated at the full retail rate, which includes energy, transmission, and distribution costs. Systems greater than $1 \mathrm{MW}$, but less than 2

\footnotetext{
${ }^{15}$ For more information on Arizona's program see: http://programs.dsireusa.org/system/program/detail/3093.

${ }^{16}$ For more information on North Dakota's NEM program see: http://programs.dsireusa.org/system/program/detail/285.
} 
MW, are credited at about $60 \%$ of the full retail rate to ensure the projects contribute to distribution and other costs. ${ }^{17}$ Credits can be carried forward indefinitely to offset future electricity demand; however, once the state reaches 1,600 MW of aggregate distributed solar capacity, utilities can propose minimum fixed bills for net-metered customers.

Finally, Oregon's NEM program compensates all qualifying DPV projects at the full retail rate. ${ }^{18}$ In addition, these credits can roll over to future billing cycles over a 12-month period to offset future electricity consumption. If the customer has unused credits after that 12-month period, those credits are compensated at the utility's avoided cost.

\subsection{NEM Studies}

Several states have commissioned studies to evaluate the overall benefits and costs of NEM programs to determine whether these programs are a net positive for ratepayers. In some cases, like in California, studies have shown NEM programs to result in some net cost to utilities, but in other studies, NEM programs have not been shown to result in added cost for nonparticipating ratepayers (California Public Utilities Commission 2013; Vermont Public Service Department 2013; Flores-Espino 2015; Rocky Mountain Institute 2013). ${ }^{19}$ These types of studies are becoming more frequent as DPV penetration levels rise and policymakers evaluate the impacts of long-standing NEM programs in an environment with declining DPV system costs. Figure 6 highlights states that have either conducted or initiated NEM studies in the United States.

\footnotetext{
${ }^{17}$ For more information on the Massachusetts NEM program, see: http://programs.dsireusa.org/system/program/detail/281.

${ }^{18}$ For more information on Oregon's NEM program, see: http://programs.dsireusa.org/system/program/detail/39.

${ }^{19}$ California and Vermont, cited here, both have relatively high DPV penetration levels.
} 


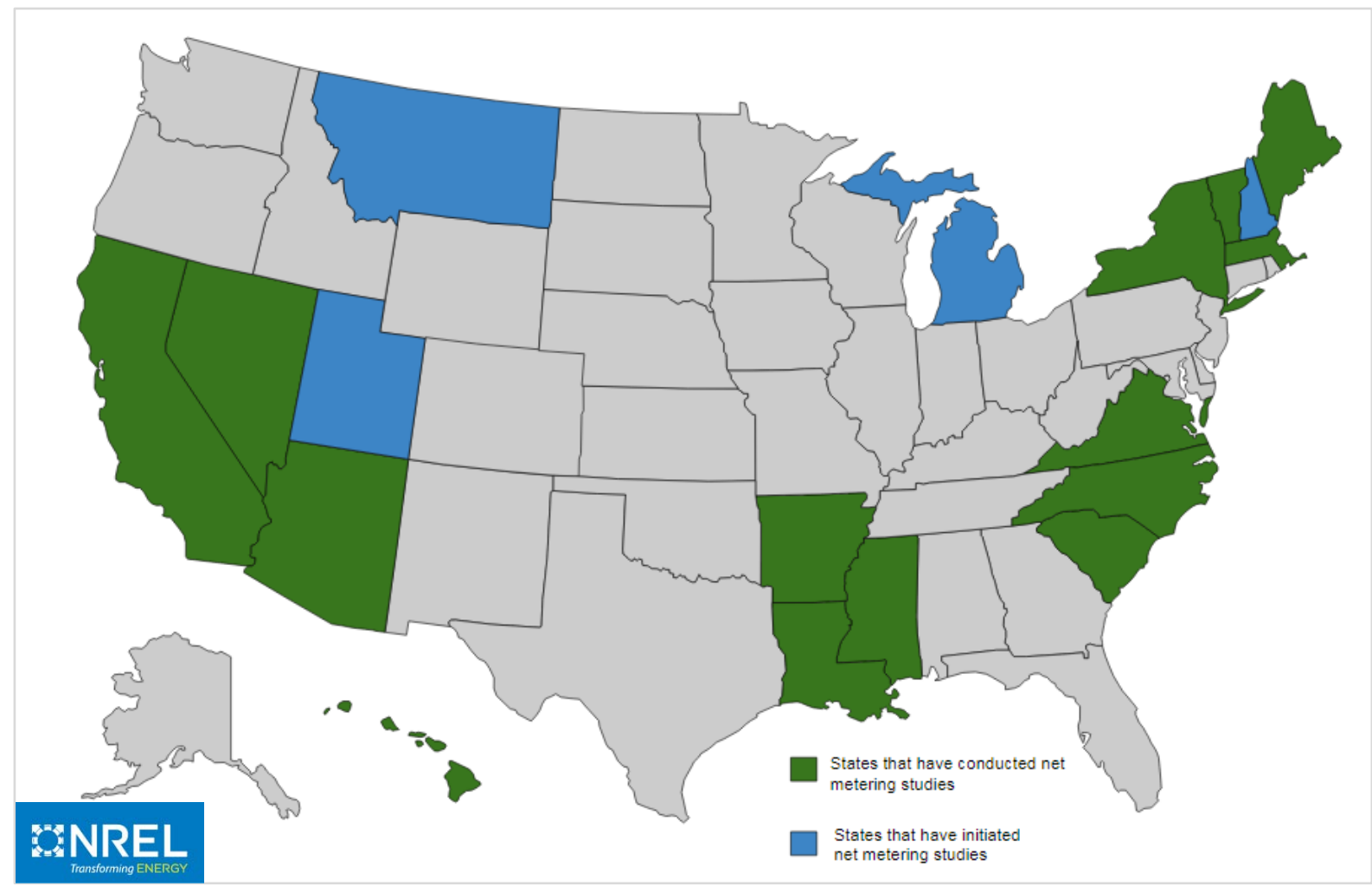

Figure 6. Map of U.S. states conducting or initiating NEM studies

Source: SEIA; Proudlove 2018; NREL

Some stakeholders have expressed concern that the combination of increasing penetration levels of DPV and compensating net excess generation at the retail rate will raise electricity rates for nonparticipating ratepayers. But as a 2017 LBNL report concluded, "for the overwhelming majority of utilities, current PV penetration levels are far too low to result in any discernible effect on retail electricity prices, even under the most pessimistic assumptions about the VOS and generous assumptions about compensation provided to solar customers (e.g., full [net energy metering] with volumetric rates)" (Barbose 2017, 10). As of $2015,{ }^{20}$ only eight utilities across the United States had reached DPV penetration levels above 5\% of retail electricity sales, and the average DPV penetration levels across all U.S. utilities was $0.4 \%$, the majority falling well below that (Barbose 2017). ${ }^{21}$

In addition to the LBNL analysis, many state-commissioned studies on NEM have found that, in general, current DPV penetration levels do not result in cost-shifting to non-DPV customers (Flores-Espino 2015); however, discussions about cost-shifting, paired with rising DPV penetration levels, are spurring demand for more sophisticated mechanisms to evaluate and quantify the costs and benefits of DPV.

\footnotetext{
${ }^{20}$ Most recent data available. Additional DPV capacity deployed since 2015 is not reflected.

${ }^{21}$ For a modeled analysis of the potential impacts of DPV compensation scenarios on average retail electricity rates at different penetration levels, refer to the 2017 LBNL report, Putting the Potential Rate Impacts of Distributed Solar into Context, available at https://emp.lbl.gov/publications/putting-potential-rate-impacts.
} 


\section{VOS}

VOS, whether applied to VOS tariffs or VOS studies, broadly refers to methodologies for quantifying the costs and benefits associated with DPV in a given location. A VOS tariff is an adopted regulatory method for compensating DPV system owners for the value their systems provide to the electrical grid. ${ }^{22}$ Through a bottom-up calculation, a VOS tariff quantifies the net benefits and costs (i.e., the net value) of distributed solar which entails a separate calculation for each component. While each region may emphasize or include different variables, the VOS tariffs may include the following components: energy, generation capacity, T\&D losses, T\&D capacity, environmental costs and benefits, ancillary services and other costs (e.g., integration costs and program administration costs). VOS studies are evaluations that could result in adoption of a tariff eventually, or may not result in any regulatory action. Studies may document factors such as the variables being considered in a market (e.g., at the state level or for a single utility service territory), different stakeholder perspectives, and overarching cost-benefit considerations. In the United States, VOS studies are more common than adopted VOS tariffs.

There are multiple ways to quantify the net cost-benefit value of DPV generation in terms of costs and benefits to the utility, the electricity-generating customer, and the non-electricity generating customer. Outcomes of the calculations of the VOS depend on location, time scale, the relative degree of the importance decision makers place on the factors being measured, and the complexity of methods used. VOS tariffs can be fixed for a specific contract length or be revisited periodically to reflect changes in DPV value over time.

To date, no standard methodology exists to calculate distributed solar costs and benefits, but the following seven overarching sources (or categories) of value are often used (Denholm et al. 2014):

- Energy

- T\&D loss savings

- Generator capacity

- T\&D capacity

- Environmental costs and benefits (e.g., emissions reductions)

- Ancillary services

- Other (e.g., fuel price hedging, market-price suppression).

VOS tariffs and studies are emerging, and states have taken different approaches to evaluating which variables to include and how to calculate the value of each (see Table 2). As VOS is a relatively uncommon approach, there is also a high degree of variability in how terms are used across VOS analyses. For the purpose of this report, we use the broad categories highlighted above, and note differences in terminology among state studies where applicable.

\footnotetext{
${ }^{22}$ This report discusses DPV valuation generally. VOS refers to a specific approach for compensating excess generation from DPV, usually under a buy-all, sell-all scheme.
} 
Table 2. Factors Considered in Determining VOS Value in Selected Jurisdictions

$(\checkmark=$ Included, $X=$ Not Included $)$

\begin{tabular}{|c|c|c|c|c|c|c|c|}
\hline VOS Component & $\begin{array}{l}\text { Austin } \\
\left(\text { Tariff^}^{\wedge}\right)\end{array}$ & $\begin{array}{l}\text { Minnesota } \\
\text { (Tariff^) }\end{array}$ & $\begin{array}{l}\text { Oregon (Utility- } \\
\text { specific Tariff^) }\end{array}$ & Maine & $\begin{array}{l}\text { New Jersey and } \\
\text { Pennsylvania }\end{array}$ & Utah & $\begin{array}{l}\text { Washington, } \\
\text { D.C. }\end{array}$ \\
\hline Energy production* & $\checkmark$ & $\checkmark$ & $\checkmark$ & $\checkmark$ & $\checkmark$ & $\checkmark$ & $\checkmark$ \\
\hline Generation capacity & $\checkmark$ & $\checkmark$ & $\checkmark$ & $\checkmark$ & $\checkmark$ & $\checkmark$ & $\checkmark$ \\
\hline $\begin{array}{l}\text { Transmission \& } \\
\text { distribution capacity } \\
\text { deferrals }\end{array}$ & $\checkmark$ & $\checkmark$ & $\checkmark$ & $\begin{array}{c}\text { Transmission } \\
\text { included; distribution } \\
\text { not included }\end{array}$ & $\checkmark$ & $\checkmark$ & $\checkmark$ \\
\hline $\begin{array}{l}\text { Transmission \& } \\
\text { distribution line losses }\end{array}$ & $\checkmark$ & $\checkmark$ & $\checkmark$ & $\checkmark$ & $X$ & $\checkmark$ & $\checkmark$ \\
\hline $\begin{array}{l}\text { Environmental costs and } \\
\text { benefits }\end{array}$ & $\checkmark$ & $\checkmark$ & $\begin{array}{l}\text { Placeholder; can be } \\
\text { developed in future }\end{array}$ & $\checkmark$ & $\checkmark$ & $\checkmark$ & $\checkmark$ \\
\hline $\begin{array}{l}\text { Natural gas (or other fuel) } \\
\text { price hedge }\end{array}$ & $\checkmark$ & $\begin{array}{l}\text { Implicitly included } \\
\text { in avoided fuel } \\
\text { costs methods }\end{array}$ & $\checkmark$ & $\begin{array}{l}\text { Not included; } \\
\text { placeholder** }^{*}\end{array}$ & $\checkmark$ & $\checkmark$ & $\checkmark$ \\
\hline $\begin{array}{l}\text { Disaster recovery (also } \\
\text { called security/resiliency) }\end{array}$ & $\checkmark$ & $\mathrm{X}$ & $X$ & $X$ & $\checkmark$ & $X$ & $\checkmark * * * *$ \\
\hline Reactive power control ${ }^{* * *}$ & $\checkmark$ & $\mathrm{X}$ & $\begin{array}{l}\text { Placeholder; can be } \\
\text { developed in future }\end{array}$ & $\mathrm{X}$ & $\mathrm{X}$ & $\mathrm{X}$ & $\checkmark$ \\
\hline Voltage control ${ }^{* * *}$ & $X$ & $\begin{array}{l}\text { Placeholder; can } \\
\text { be developed in } \\
\text { future }\end{array}$ & $\begin{array}{l}\text { Placeholder; can be } \\
\text { developed in future }\end{array}$ & $\begin{array}{l}\text { Not included; } \\
\text { placeholder }\end{array}$ & $\mathrm{X}$ & $X$ & $\checkmark$ \\
\hline Solar integration costs & $X$ & $\begin{array}{l}\text { Placeholder; can } \\
\text { be developed in } \\
\text { future }\end{array}$ & $\checkmark$ & $\checkmark$ & $\checkmark$ & $X$ & $\checkmark$ \\
\hline $\begin{array}{l}\text { Credit for local } \\
\text { manufacturing \& assembly }\end{array}$ & $X$ & $\begin{array}{l}\text { Considered, but } \\
\text { not adopted }\end{array}$ & $X$ & $X$ & $X$ & $X$ & $X$ \\
\hline Market price reduction & $\mathrm{X}$ & $\begin{array}{l}\text { Considered, but } \\
\text { not adopted }\end{array}$ & $\checkmark$ & $\checkmark$ & $\checkmark$ & $X$ & $\checkmark$ \\
\hline $\begin{array}{l}\text { High-value location credit } \\
\text { for PV system }\end{array}$ & $\mathrm{X}$ & Optional for utility & $\mathrm{X}$ & $\mathrm{X}$ & $\mathrm{X}$ & $\mathrm{X}$ & $\mathrm{X}$ \\
\hline $\begin{array}{l}\text { Economic development } \\
\text { value }\end{array}$ & $X$ & $X$ & $X$ & $X$ & $\checkmark$ & $X$ & $X$ \\
\hline
\end{tabular}

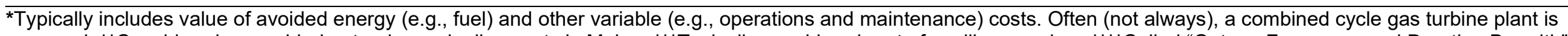

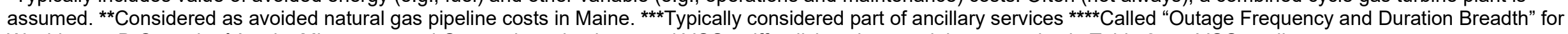
Washington D.C. study. ^Austin, Minnesota, and Oregon have implemented VOS tariff policies; the remaining examples in Table 2 are VOS studies.

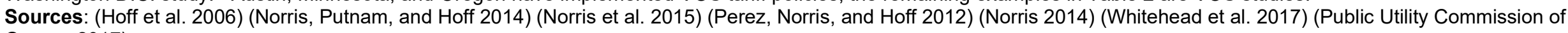
Oregon 2017). 


\subsection{U.S. Experience with VOS Tariff Policies}

As of August 2018, only three U.S. jurisdictions-Austin, Texas (2012), Minnesota (2014), and Oregon (2017) — had implemented VOS tariff policies, although 17 additional states have analyzed the value of DPV generally. Oregon's VOS tariff is utility-specific. In Austin, Texas, and Minnesota, both jurisdictions' VOS tariffs have been implemented in buy-all, sell-all schemes. The DPV customer purchases all of its electricity needs from the grid at the retail rate and sells all energy produced by their DPV system to the utility at the VOS rate (under this scenario, there is no on-site, or self-consumption, of the electricity generated by the DPV system). ${ }^{23}$ Minnesota and Austin include both distinct and overlapping components in their VOS calculations (see Table 2). This section offers a summary of each tariff. ${ }^{24}$

\subsubsection{Austin, Texas Tariff}

In 2012, Austin Energy, a municipal utility, enacted a VOS tariff that was later approved by the city council. From 2012-2018, residential customers have been offered a predetermined VOS tariff (see Figure 7) (Austin Energy 2017; Austin Energy 2018).

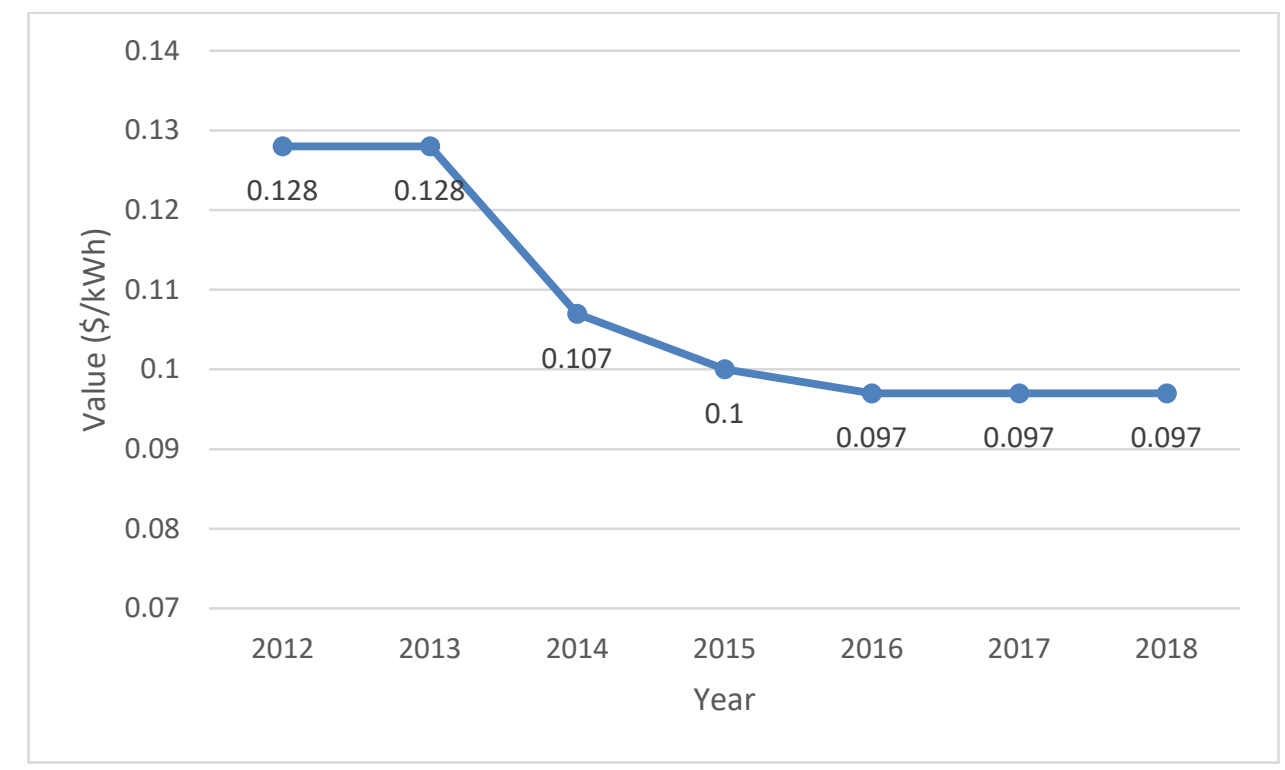

Figure 7. Austin Energy's annual VOS tariff rate schedule, 2012-2018

Source: Austin Energy 2018; NREL

Key components of Austin Energy's VOS tariff:

- VOS tariff is adjusted annually for all customers; and

\footnotetext{
${ }^{23}$ Though these jurisdictions compensate DPV in this fashion, VOS tariffs can also be used in behind-the-meter situations that include self-consumption.

${ }^{24}$ Detailed analysis is available in the 2015 NREL report, Value of Solar: Program Design and Implementation Considerations, https://www.nrel.gov/docs/fy15osti/62361.pdf.
} 
- To reduce price volatility, a five-year rolling average VOS tariff is used to calculate the rate each year. Thus, even though the 2018 estimate was $8.5 \phi / \mathrm{kWh}$, the five-year rolling average VOS tariff remained at $9.7 \phi / \mathrm{kWh}$.

\subsubsection{Minnesota Tariff}

In 2013, Minnesota passed legislation requiring the Minnesota Department of Commerce (MN DOC) to develop a methodology for calculating a VOS tariff. The legislation required the rate methodology to consider the costs and benefits of energy and its delivery, generation and transmission capacity, and T\&D line losses, as well as environmental costs and benefits. The legislation further instructed the MN DOC to consider other costs and benefits such as locally manufactured content and locational value on the grid. ${ }^{25}$

After a series of stakeholder workshops to elicit feedback, the MN DOC submitted a VOS methodology in early 2014 that was approved by the Minnesota Public Utility Commission (PUC) shortly thereafter. Use of the VOS tariff is voluntary for Minnesota's investor-owned utilities. To date, no utilities have voluntarily adopted the VOS tariff in lieu of NEM; however, in September 2016, the Minnesota PUC mandated that, beginning in January 2017, utilities provide subscribers of new community solar gardens a VOS tariff in lieu of NEM (Hughlett 2016). Xcel Energy has since proposed the following VOS tariffs for 2017 and 2018 for their community solar garden program (Eleff 2017):

- 2017: $\$ 0.1033 / \mathrm{kWh}$

- 2018: \$0.1006/kWh.

Key components of Minnesota's VOS tariff include:

- Utilities must recalculate the VOS annually and submit to the regulator for approval;

- The VOS tariff must be above the retail rate for up to three years after the regulator has approved it; and

- A utility and customer must enter into a 20-year (minimum) contract; the customer receives the same VOS tariff for the entire length of the contract (DSIRE 2015).

\subsubsection{Oregon Tariff}

In November 2017, the Oregon PUC released a VOS methodology that three large utilitiesPortland General Electric, PacifiCorp, and Idaho Power - used to determine the VOS. Utilities are now obligated to use a VOS tariff. The methodology requires the consideration of:

- Energy

- Generation capacity

- T\&D capacity

- Line losses

- Integration and administration costs

- Grid services (treated as placeholder in initial filings)

- Hedge value

\footnotetext{
${ }^{25}$ Minnesota Statutes 2017, section 216B.164, subdivision 10f. https://www.revisor.mn.gov/statutes/cite/216b.164.
} 
- Market price

- Environmental compliance (treated as a placeholder in initial filings). ${ }^{26}$

\subsection{U.S. Experience with VOS Studies}

Other states and jurisdictions have conducted VOS studies but have not instituted a VOS tariff (see Figure 8). Some of these studies are summarized below. VOS studies vary in numerous ways, including which costs and benefits are considered, which perspectives are considered, data and methodological assumptions, and other factors. Some methodologies are broad in scope, looking holistically at different costs and benefits, while others have a narrower focus. The terminology itself also varies across studies. Even within a common valuation category, such as environmental cost-benefit considerations, studies may determine net value in different ways (e.g., environmental compliance costs and cost of carbon).

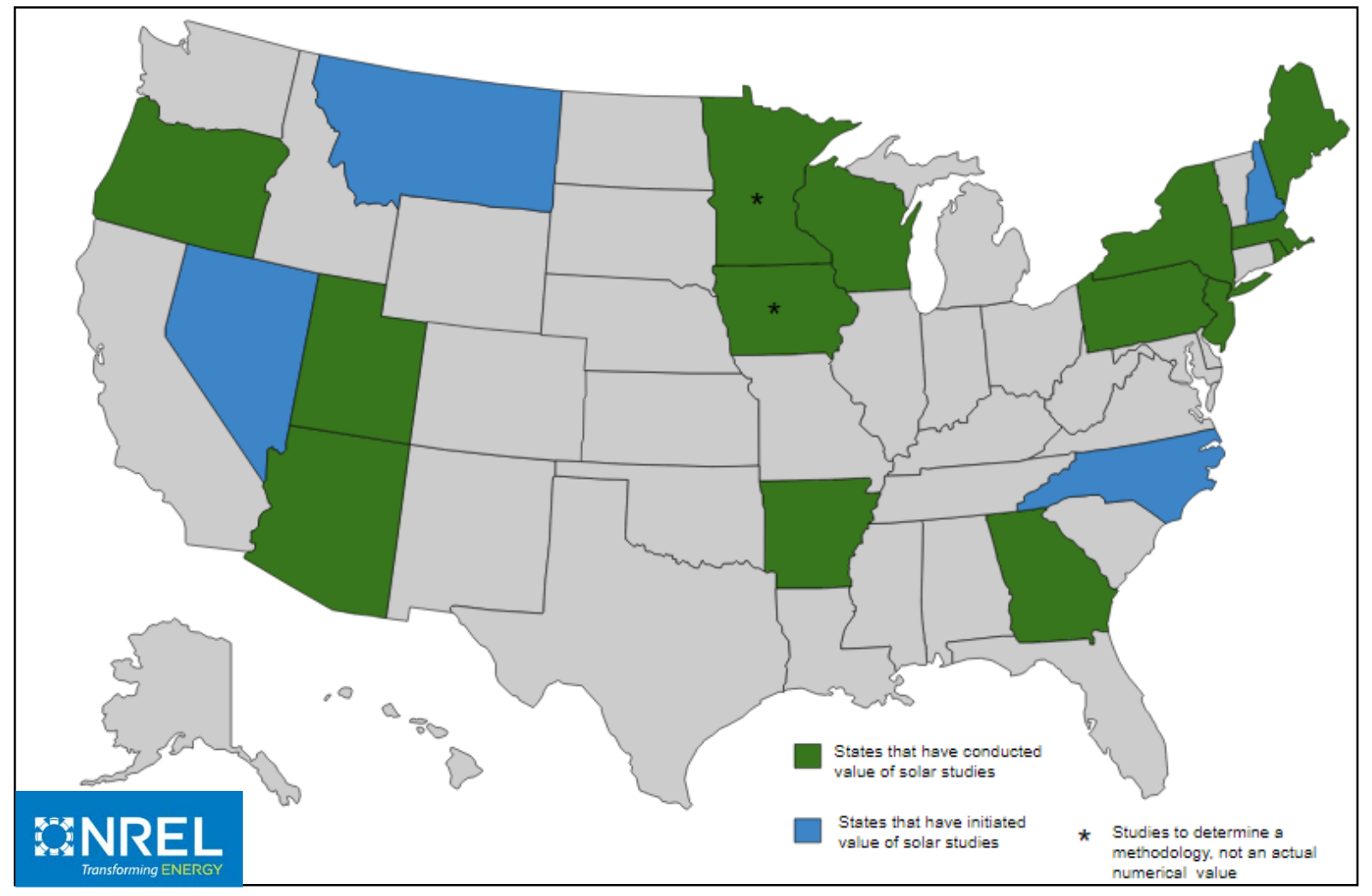

Figure 8. Map of U.S. states conducting or initiating VOS studies

Source: SEIA; Proudlove 2018; NREL

Findings from a sampling of these studies are described below, and a comparison of the variables considered is included below.

\footnotetext{
${ }^{26}$ Public Utility Commission of Oregon, Order No. 17357 (September 15, 2017). http://apps.puc.state.or.us/orders/2017ords/17-357.pdf.
} 


\subsubsection{Maine Study}

In 2014, the Maine Legislature passed the Act to Support Solar Energy Development, requiring the PUC to determine the VOS in Maine. ${ }^{27}$ The PUC hired Clean Power Research,${ }^{28}$ who conducted and published a Maine Distributed Solar Valuation Study. The following value components were to be included, at minimum, by statute:

- Net value of energy

- Market price effects for energy production

- Net value of delivery

- Net value of generation capacity

- Net value of transmission capacity

- T\&D line losses

- Societal net value (i.e., costs and benefits) of the environmental impacts.

The study looks at three utility service territories in Maine and calculated both a first-year VOS and a 25-year levelized VOS (Norris et al. 2015):

- First-year VOS: $\$ 0.182 / \mathrm{kWh}$

- 25-year levelized VOS: $\$ 0.337 / \mathrm{kWh}$.

These VOS study values are notably higher than Maine's residential retail rate of electricity and other VOS in different jurisdictions. Some of this heightened value can be attributed to the environmental benefits (net social cost of carbon, $\mathrm{SO}_{2}$, and $\mathrm{NO}_{\mathrm{x}}$ ), calculated at $\$ 0.09 / \mathrm{kWh}$ (for 25 -year levelized), and more contentious factors that are difficult to quantify, such as market price response and avoided fuel price uncertainty (Labrador 2015).

\subsubsection{New Jersey and Pennsylvania Study}

In 2012, Clean Power Research published a study evaluating the value of distributed solar for a "fleet" of systems (i.e., a set of larger DG systems) in seven different locations across New Jersey and Pennsylvania and six utility service territories. The analysis determined a levelized net value of distributed solar ranging from $\$ 0.256-\$ 0.318 / \mathrm{kWh}$ across the different locations (Perez, Norris, and Hoff 2012).

\subsubsection{Utah Study}

In 2014, Clean Power Research prepared a VOS study focused on the Rocky Mountain Power service territory in Utah for Utah Clean Energy. This study determined the VOS to be $\$ 0.116 / \mathrm{kWh}$ (levelized over 25-year period) (Norris 2014).

\footnotetext{
${ }^{27}$ Public Law, Chapter 562, $126^{\text {th }}$ Maine Legislature. An Act to Support Solar Energy Development in Maine. Sec. 1. 35-A MRSA c. 34-B. https://www.mainelegislature.org/legis/bills/bills_126th/chapters/PUBLIC562.asp

${ }^{28}$ Clean Power Research conducted the Austin VOS methodology and has conducted similar studies in other states.
} 


\subsubsection{Washington, D.C. Study}

A VOS study for Washington D.C. calculates two different VOS - a utility system total net value and a societal total net value - with each including different (but also many similar) components (Whited et al. 2017):

- Utility system total VOS (levelized for 2017-2049): $\$ 0.132 / \mathrm{kWh}$

- Societal total VOS (levelized for 2017-2049): \$0.194/kWh.

\subsection{VOS Considerations}

The VOS determined by one tariff or study for a particular jurisdiction should not be compared to another tariff or study's VOS at face value, due to methodological differences and variations in the terminology used. VOS studies do not yield an apples-to-apples comparison in DPV value. Methodological differences also contribute to the variance among estimated net cost-benefit values of solar compared to state (or jurisdictional) retail electricity rates, as shown in Figure 9. Note that in Figure 9, 2017 retail rates are compared to the values calculated from VOS studies. In the cases of Maine, New Jersey, Pennsylvania, Utah, and Washington, D.C., the VOS study values were calculated in previous years. For Minnesota and Austin, the VOS tariffs are current for 2018. The figure represents a snapshot in time.

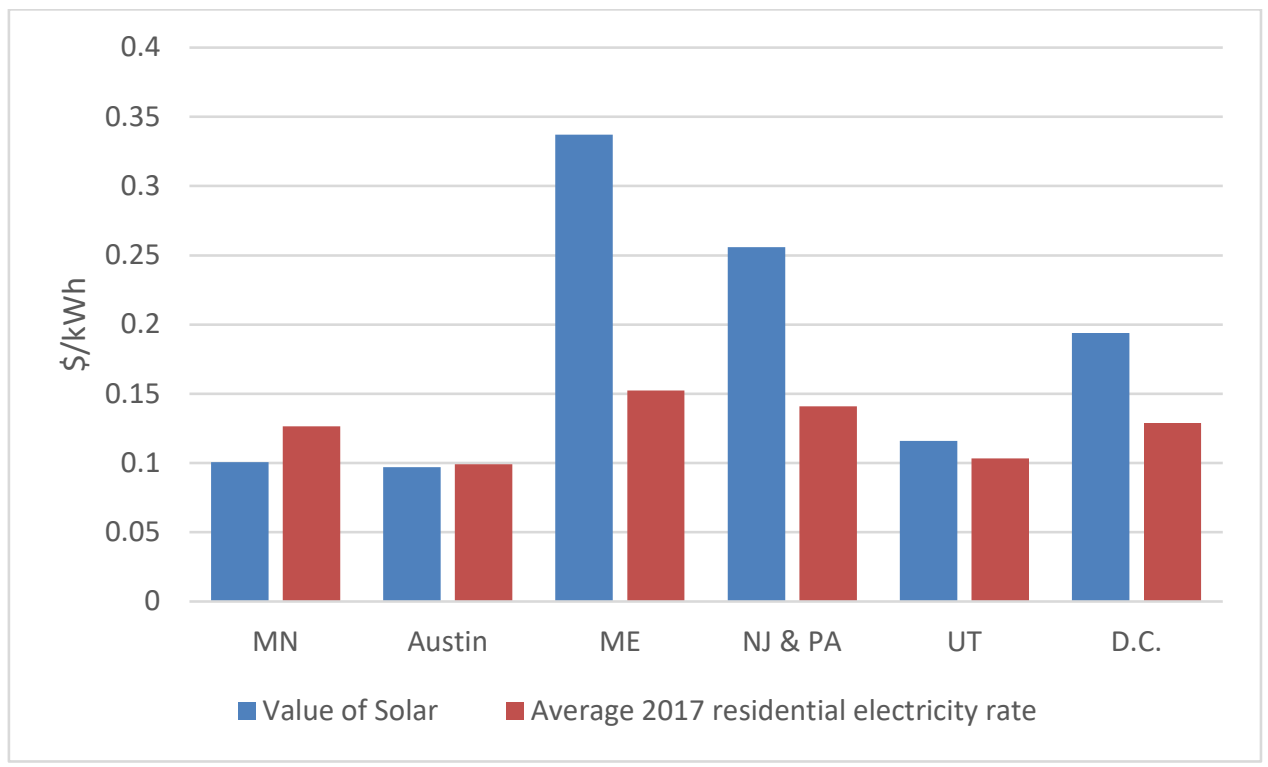

Figure 9. Comparison of VOS values to local retail electricity rates

Sources: Hoff et al. 2006; Norris, Putnam, and Hoff 2014; Norris et al. 2015; Perez, Norris, and Hoff 2012; Norris 2014; Whitehead et al. 2017; NREL

Table 2 demonstrates this variation by showing which factors were included in selected state VOS studies and tariffs. ${ }^{29}$

\footnotetext{
${ }^{29}$ For a complete list of value of solar and net energy metering cost benefit studies, see https://www.seia.org/initiatives/solar-cost-benefit-studies.
} 


\subsection{VOS Summary}

As a growing number of VOS tariffs are being adopted and VOS studies are being conducted, several important considerations and lessons learned are emerging. In general, VOS study and tariff methodology development can result in a transparent methodology that incorporates multiple stakeholder perspectives (e.g., the utility, the distributed solar system owner, ratepayers, and society). Furthermore, if a VOS calculation is applied in a buy-all, sell-all scheme, as has been done thus far in the United States, then solar production and a customer's electricity consumption are decoupled. VOS methodologies can also be adapted to reflect granular distributed solar value at different times and locations, though this granularity comes with increased complexity and potential customer confusion (Zinaman et al. 2017).

While a transparent process and robust stakeholder engagement are typically considered benefits of a VOS process, developing a VOS methodology can be complex and time consuming, and there is currently no established, uniform approach to evaluating and designing VOS tariffs and studies. Gaining consensus from multiple stakeholders can be challenging. Additionally, VOS tariffs are most often recalculated annually. In some jurisdictions, the payment to the solar owner is constant and set at the time the project comes on-line which provides revenue certainty. In other jurisdictions, the amount provided is adjusted in future years; in this case, prospective distributed solar owners and the broader solar industry may face uncertainty regarding future compensation. 


\section{Variables Considered in Solar Net Cost-Benefit Valuation and Compensation}

A wide range of factors are considered in DPV valuation and compensation structures nationwide. In addition to structural variations in how DPV compensation policies are implemented (e.g., contract length, crediting terms), there are also differences among what factors are included in evaluating the costs and benefits of DPV. The goal of this section is to clarify which variables have, or could be, considered in a DPV cost-benefit framework, and what methodologies exist to address those variables. The information presented here is intended to be a primer for follow-on work with OSEE delving into more detail on each of these factors and evaluation approaches; as such, we do not define every concept or explore the relative merits of every methodology in this report. To help structure this section, we rely on the work of Denholm et al. (2014) and organize DPV value components in the following categories:

- Energy

- T\&D losses

- Generation capacity

- Transmission capacity

- Distribution capacity

- Environmental costs and benefits

- Ancillary services

- Other factors.

How these variables are evaluated will themselves depend on several variables, including the stakeholder perspective (discussed in Section 6), time frame assessed, and locational siting considerations. For example, in the short term, the net value associated with deferring T\&D capacity may be minimal, whereas the net value would be higher in the longer term. Thus, the time frame lens through which solar compensation variables are considered is significant. These values also change over time, as the general characteristics of the electric system change. Therefore, it is important to update the analysis regularly, at least annually, ${ }^{30}$ to capture the evolving utility system. Locational considerations in siting, such as where DPV systems could contribute to deferring distribution system upgrades or reducing grid congestion, can also influence DPV valuation. DPV costs and benefits may vary at different points on the electric grid.

\subsection{Energy}

The energy category refers to the costs and benefits from the actual electricity generation of the DPV system (in kWh or MWh). This is integral to VOS frameworks, as well as NEM and billing programs that compensate DPV systems at the avoided cost of generation. DPV systems can displace generation from peaking power plants, or those facilities deployed to meet consumer demand at peak times. To maximize the benefit of DPV generation, a utility seeks to offset generation at the highest-cost power generator. DPV can also provide energy benefits during shoulder and non-peak times. There are five common methods for quantifying what power plants

\footnotetext{
${ }^{30}$ Sometimes annual updates are applied to all customers and sometimes just to new participants.
} 
are effectively "on the margin" and able to reduce output to accommodate DPV generation. These include (in increasing order of complexity and precision):

- Simple avoided generator

- Weighted avoided generator

- Market price

- Simple dispatch

- Production simulation.

\subsection{T\&D Losses}

DPV systems, especially in residential markets, are located close to the load. This contrasts with large centralized power plants, which are often located far from population centers, and electricity is transported to these areas via a series of high-voltage transmission lines and then lower-voltage distribution lines. Electricity is lost in transit and these losses are typically lower, if they exist at all, for DPV systems, due to their proximity to load. Quantifying displaced electricity losses at marginal power generators can be important in estimating the net value provided by DPV. To date, NEM programs typically do not quantify this input, while it is incorporated in both Austin and Minnesota VOS tariff frameworks. Four methodologies for quantifying T\&D losses include (in increasing order of complexity and precision):

- Average combined loss rate

- Marginal combined loss rate

- Locational marginal loss rate

- Loss rate using power flow models.

\subsection{Generation Capacity}

Customers' bills consist of not only energy charges, but also fixed charges or costs (in $\$ / \mathrm{kW}$ ). The ability of DPV to reduce the capital costs associated with building power plants and T\&D infrastructure is called its capacity value. Estimating the generation capacity value of DPV requires calculating the actual fraction of a DPV system's capacity that could reliably be used to offset conventional capacity.

\subsection{Transmission Capacity}

DPV installations can affect both congestion and reliability in the transmission system and can decrease or increase distribution system capacity investments. A large enough concentration of DPV at one location can relieve the transmission network and reduce the need for additional transmission capacity; this may not always be true in terms of distribution capacity. DPV can offset investments required to maintain reliability, or accommodate growth in certain load pockets, given the local generation can be used to offset local grid needs. But high local penetrations of DPV may require upgrading wires, transformers, and voltage-regulation devices that could offset some or all the aforementioned benefits.

\subsection{Distribution Capacity}

Though DPV typically provides net benefits for generation and transmission deferrals, this may not always be true in terms of distribution capacity. First, DPV can offset investments required to maintain reliability, or accommodate growth in certain load pockets, given the local generation can be used to offset local grid needs. High local penetrations of DPV may require upgrading 
wires, transformers, and voltage-regulation devices that could offset some or all the aforementioned benefits. Therefore, clarifying the net costs is important for fair compensation. This value is assessed in existing VOS programs and can be quantified in the following ways (in increasing order of complexity and precision):

- PV capacity limited to current hosting capacity

- Average deferred investment of peak reduction

- Marginal analysis based on curve fits

- Least-cost adaptation for higher PV penetration

- Deferred expansion value

- Automated distribution scenario planning.

\subsection{Environmental Costs and Benefits}

Quantifying environmental costs and benefits is just beginning to be incorporated into certain VOS programs, such as Austin Energy's program, which quantifies emissions reductions. There are a variety of environmental costs and benefits that can be considered when assessing DPV net cost-benefit value. Quantifying these net benefits begins from the methodology selected to identify the marginal units used to estimate energy savings (see Section 5.1). This analysis will clarify which generators are displaced and, from them, estimate avoided emissions and related costs and benefits (e.g., avoided renewable portfolio standard compliance costs, reduced water consumption, and reductions in land impacts). Though not necessarily straightforward or easy, these impacts can be conducted in conjunction with the energy analyses, as opposed to being evaluated separately.

\subsection{Ancillary Services}

Ancillary services represent a broad set of grid-related costs and benefits that DPV systems may provide, such as voltage control and operating reserves. Quantifying these services is challenging in part because it is unclear that DPV systems can provide these benefits, largely because penetration levels are too low, and controls are not sophisticated enough yet. As a result, many states have not included these in their VOS frameworks, though some locations, like Minnesota, have left it open to consider these impacts in the future. Ultimately, two approaches have been used to quantify these impacts:

- Simple cost-based methods, or

- Detailed cost-benefit analysis.

\subsection{Assessing Other Costs and Benefits}

There are a wide variety of other costs and benefits that have been evaluated in certain contexts. As DPV systems become integrated in holistic solar-plus configurations, which include energy storage, among other options, this may generate additional cost-benefit streams to quantify. Similarly, discussions surrounding how to evaluate the resilience benefits provided by solar-plusstorage and other DG systems during grid outages may also begin factoring into DPV valuation. Other variables considered in VOS frameworks include fuel price hedging, market-price suppression, economic development, locational value, administrative costs, integration costs, and others. Ultimately, states may be interested in including these impacts in their compensation structures, but, as with other costs and benefits, methodologies vary. 


\section{Compensation-Related Considerations for Key Stakeholders}

The relative emphasis placed on the DPV cost-benefit variables often vary based on the stakeholder group evaluating them. Four key stakeholders in DPV compensation discussions include the DPV system owner, other ratepayers, the utility, and policymakers, representing society at large.

Among the DPV system owner's primary concerns is typically how compensation rates may influence DPV system payback periods. If PV exports are compensated at the avoided cost rate, it will take longer to recoup the investment than under a scenario where the excess generation is compensated at the full retail rate. Another risk DPV consumers face is that compensation structures may change after installing the system; policymakers actively consider new compensation models, which can influence existing customer rates. Though in many cases existing customers' rate schedules have been grandfathered into new programs, this is not guaranteed, as illustrated recently by policy changes in Nevada (Bebon 2016), though these changes were later reversed.

Conversely, the ratepayers who do not participate in on-site DPV may benefit from the local generation and have their own concerns about increasing rates. Other ratepayers may benefit from decreased capacity costs, energy costs, and grid support services, to the extent the DPV delays or defrays additional investment and provides these services to the utility; however, other ratepayers may end up paying more because administrative costs increase, and the costs of rebates or incentives may be borne by all utility customers.

In comparison, two key compensation issues for utilities are the extent to which they can recoup fixed costs of the electric system and whether the DPV customer pays for grid services the utility provides. Because most utilities have historically structured their rates volumetrically, DPV customers may pay less — or in some cases, nothing - for fixed-grid costs related to T\&D equipment. If more customers adopt DPV and are credited the full retail rate, the utility may not be able to recoup grid-related investments that arise from DPV. This has resulted in some utilities pursuing rate increases designed to cover these costs. In addition, utilities may also question whether crediting value at the full retail rate is justified, given the important role that the utility plays in offering reliable, standby power at all times of the day. Among typical utility concerns is that DPV customers are not paying for the reliability provided by the utility, especially in a situation where credits are rolled over and used to offset future grid consumption.

Finally, policymakers are typically concerned with the potential impact of this compensation on all ratepayers in the state. This perspective largely stems from the utility concern that DPV customers may not pay their fair share of fixed costs, or a ratepayer concern that non-participants have an increased burden to support the overall system. Additionally, policymakers may be interested in other societal or environmental costs and benefits that accrue across society, rather than to a single DPV system owner or other stakeholder.

Table 3 summarizes key factors from different sector perspectives that may influence how these different stakeholders approach DPV compensation dialogue. 
Table 3. Distributed Solar PV Perspectives

\begin{tabular}{ll}
\hline Stakeholder Perspective & Factors Affecting Value \\
\hline DPV system owner & $\begin{array}{l}\text { Benefits: Reduced utility bill, utility or state incentives, federal tax } \\
\text { credits, consumer empowerment } \\
\text { Costs: DG system capital cost }\end{array}$ \\
$\begin{array}{l}\text { Other customers (i.e., } \\
\text { ratepayers) }\end{array}$ & $\begin{array}{l}\text { Benefits: Potential reduction in transmission, distribution, and generation } \\
\text { costs, ability to capture capacity benefits, ability to capture energy } \\
\text { benefits, and reduction of grid support services (depending on levels of } \\
\text { DPV deployment) } \\
\text { Costs: Administrative costs, cost of rebates/incentives }\end{array}$ \\
Utility operations & $\begin{array}{l}\text { Benefits: Reduction in capacity costs, energy costs, and grid support } \\
\text { services } \\
\text { Costs: Administrative costs, cost of rebates/incentives, decreased } \\
\text { revenue, integration and interconnection costs }\end{array}$ \\
Policymakers, society & $\begin{array}{l}\text { Sum of the benefits and costs to all stakeholders plus additional societal } \\
\text { and environmental costs and benefits that accrue to society at large, } \\
\text { rather than any individual stakeholder. }\end{array}$ \\
\hline
\end{tabular}

Understanding these varying perspectives is important for understanding how different interests might approach DPV, while revealing some of the important considerations to establishing a DPV compensation framework. 


\section{Conclusions and Next Steps}

There are many factors to consider when quantifying the costs and benefits of DPV to the electrical grid. At the same time, there are a wide variety of methodologies to quantify these benefits and costs. Each jurisdiction will need to consider which terms are most relevant for evaluation and their relevance and applicability in distinct contexts. The DPV market, related services, and the energy market broadly are evolving rapidly; any effort to quantify the net value of DPV to the utility system is likely to be an iterative and ongoing process.

This summary report is the first part of a two-part deliverable for OSEE. Follow-on engagement with OSEE explored DPV net valuation methodologies and potential input variables in more detail. Based on input variables identified through this baseline study, the follow-on work provides considerations around developing a methodology and decision matrix framework for quantifying the costs and benefits of DPV. The methodology includes descriptions of the potential inputs and associated considerations and approaches for quantifying identified input variables. The follow-on deliverable is available at https://www.nrel.gov/docx/gen/fy19/72165.pdf 


\section{References}

Austin Energy. “2018 Value of Solar (VOS) Update.” Presented Ay 16, 2017.

http://www.austintexas.gov/edims/document.cfm?id=277018.

_. "Value of Solar (VoS) Rate." Last modified January 2, 2018.

https://austinenergy.com/ae/green-power/solar-solutions/value-of-solar-rate.

Barbose, Galen. Putting the Potential Rate Impacts of Distributed Solar into Context. LBNL1007060. Berkeley, CA: Lawrence Berkeley National Laboratory. January 2017. http://etapublications.lbl.gov/sites/default/files/lbnl-1007060.pdf.

Bebon, Joseph. "Nevada Regulators Deny Solar NEM Grandfathering Proposal." Solar Industry Magazine. February 15, 2016. https://solarindustrymag.com/nevada-regulators-deny-solar-nemgrandfathering-proposal.

Chakka, Babu. “Austin Energy Value of Solar Methodology.” Presented May 28, 2014.

http://www.austintexas.gov/edims/document.cfm?id=210805.

CPUC (California Public Utilities Commission). California Net Energy Metering Ratepayer Impacts Evaluation. October 2013.

http://www.cpuc.ca.gov/uploadedFiles/CPUC Website/Content/Utilities and Industries/Energy/ Reports and White Papers/NEMReportwithAppendices.pdf.

Denholm, Paul, Robert Margolis, Bryan Palmintier, Clayton Barrows, Eduardo Ibanez, Lori Bird, and Jarett Zuboy. Methods for Analyzing the Benefits and Costs of Distributed Photovoltaic Generation to the U.S. Electric Utility System. NREL/TP-6A20-62447. Golden, CO: National Renewable Energy Laboratory (NREL). https://www.nrel.gov/docs/fy14osti/62447.pdf.

DSIRE (Database of State Incentives for Renewables \& Efficiency). "Value of Solar Tariff." Last modified November 2015. http://programs.dsireusa.org/system/program/detail/5666.

EIA (U.S. Energy Information Agency). "Table 4.2.B Existing Net Summer Capacity of Other Renewable Sources by Producer Type, 2006 through 2016 (Megawatts).”

https://www.eia.gov/electricity/annual/html/epa_04 02 b.html.

Eleff, Bob. “Xcel Energy's Community Solar Garden Program.” St. Paul, MN: Research Department, Minnesota House of Representatives. October 2017. http://www.house.leg.state.mn.us/hrd/pubs/solargarden.pdf.

Flores-Espino, Francisco. Compensation for Distributed Solar: A Survey of Options to Preserve Stakeholder Value. NREL/TP-6A20-62371. Golden, CO: NREL. https://www.nrel.gov/docs/fy15osti/62371.pdf.

Hoff, Thomas, Richard Perez, Gerry Braun, Michael Kuhn, Benjamin Norris. The Value of Distributed Photovoltaics to Austin Energy and the City of Austin. Prepared for Austin Energy by Clean Power Research. March 2006. https://www.cleanpower.com/wpcontent/uploads/034 PV ValueReportAustinEnergy.pdf. 
Hughlett, Mike. "Minnesota Public Utilities Commission approves size caps, rate structures for solar projects." Star Tribune, July 21, 2016. http://www.startribune.com/minnesota-utilitiescommission-approves-size-caps-rate-structure-for-solar-projects/387872592/.

Labrador, David. "What is Solar Power Really Worth to Maine?" Rocky Mountain Institute, July 29, 2015. https://www.rmi.org/news/blog_2015_07_29_what_is_solar_power_really_worth_to_maine/.

North Carolina Clean Energy Technology Center. "The 50 States of Solar: Q3 2017 Quarterly Report." October 2017. https://nccleantech.ncsu.edu/the-50-states-of-solar-report-for-q3-2017now-available/.

Norris, Benjamin. Value of Solar in Utah. Prepared for Utah Clean Energy by Clean Power Research. January 2014. https://pscdocs.utah.gov/electric/13docs/13035184/255147ExAWrightTest5-22-2014.pdf.

Norris, Benjamin, Philip Gruenhagen, Robert Grace, Po-Yu Yuen, Richard Perez, and Karl Rábago. Maine Distributed Solar Valuation Study. Prepared for the 127th Maine Legislature by Clean Power Research. March 2015. https://www.nrcm.org/wpcontent/uploads/2015/03/MPUCValueofSolarReport.pdf.

Norris, Benjamin, Morgan Putnam, and Thomas Hoff. Minnesota Value of Solar: Methodology. Prepared for the Minnesota Department of Commerce, Division of Energy Resources by Clean Power Research. January 2014. https://www.cleanpower.com/wp-content/uploads/MN-VOSMethodology-2014-01-30-FINAL.pdf.

Perez, R., B.L. Norris, T.E. Hoff. 2012. "The Value of Distributed Solar Electric Generation to New Jersey and Pennsylvania.” Prepared for the Mid-Atlantic Solar Energy Industries Association \& Pennsylvania Solar Energy Industries Association by Clean Power Research. https://www.michigan.gov/documents/mpsc/valuesolarnj pa 448375 7.pdf.

Phung, Thuy, Isabelle Riu, Nate Kaufman, Lucy Kessler, Maria Amodio, and Gyan De Silva. The Effect of Austin Energy's Value-of-Solar Tariff on Solar Installation Rates. Yale School of Forestry and Environmental Studies. May 2017. https://emp.lbl.gov/sites/default/files/1._austin_vos_paper_final 2017-06-16.pdf.

Proudlove, A., B. Lips, D. Sarkisian, and A. Shrestha. 2018. "The 50 States of Solar: 2017 Policy Review and Q4 Quarterly Report." North Carolina Clean Energy Technology Center. January 2018. https://nccleantech.ncsu.edu/the-50-states-of-solar-report-2017-annual-review-q4-updateedition-now-available/.

Public Utility Commission of Oregon. "UM 1716 Investigation to Determine the Resource Value of Solar." September 2017. http://apps.puc.state.or.us/orders/2017ords/17-357.pdf.

Taylor, Mike, Joyce McLaren, Karlynn Cory, Ted Davidovich, John Sterling, and Miriam Makhyoun. Value of Solar: Program Design and Implementation Considerations. Solar Electric Power Association. NREL/TP-6A20-62361. Golden, CO: NREL. https://www.nrel.gov/docs/fy15osti/62361.pdf. 
Vermont Public Service Department. Evaluation of Net Metering in Vermont Conducted Pursuant to Act 125 of 2012. January 2013.

http://www.leg.state.vt.us/reports/2013ExternalReports/285580.pdf.

Whited, Melissa, Ariel Horowitz, Thomas Vitolo, Wendy Ong, and Tim Woolf. Distributed Solar in the District of Columbia. Prepared for the Office of the People's Counsel for the District of Columbia by Synapse Energy Economics, Inc. April 2017. https://www.synapseenergy.com/sites/default/files/Distributed-Solar-in-DC-16-041.pdf.

Wood Mackenzie, Limited and SEIA (Solar Energy Industries Association). "U.S. Solar Market Insight Executive Summary Q4 2017.” https://www.seia.org/research-resources/solar-marketinsight-report-2017-q4.

Zinaman, Owen, Alexandra Aznar, Carl Linvill, Naïm Darghouth, Timon Dubbeling, and Emanuele Bianco. "Grid-Connected Distributed Generation: Compensation Mechanism Basics." NREL/BR-6A20-68469. Golden, CO: National Renewable Energy Laboratory. October 2017. https://www.nrel.gov/docs/fy18osti/68469.pdf. 


\section{Appendix A. Additional Reading}

\section{A.1 Valuation Considerations}

Barbose, G., J. Miller, B. Sigrin, E. Reiter, K. Cory, J. McLaren, J. Seel, A. Mills, N. Darghouth, A. Satchwell. 2016. "On the Path to SunShot: Utility Regulatory and Business Model Reforms for Addressing the Financial Impacts of Distributed Solar on Utilities." Golden, CO: National Renewable Energy Laboratory. NREL/TP-6A20-65670.

http://www.nrel.gov/docs/fy16osti/65670.pdf.

Bird, L., J. McLaren, J. Heeter, C. Linvill, J. Shenot, R. Sedano, and J. Migden-Ostrander. 2013. "Regulatory Considerations Associated with the Expanded Adoption of Distributed Solar." NREL/TP-6A20-60613. Golden, CO: National Renewable Energy Laboratory. http://www.nrel.gov/docs/fy14osti/60613.pdf.

Bird, L., A. Reger, and J. Heeter. 2012. "Distributed Solar Incentive Programs: Recent Experience and Best Practices for Design and Implementation." NREL/TP-6A20-56308. Golden, CO: National Renewable Energy Laboratory. http://www.nrel.gov/docs/fy13osti/56308.pdf.

Blackburn, G., C. Magee, and V. Rai. 2014. "Solar Valuation and the Modern Utility's Expansion into Distributed Generation." The Electricity Journal. https://www.sciencedirect.com/science/article/pii/S1040619013002868.

Hansen, L., V. Lacy, and D. Glick. 2013. “A Review of Solar PV Benefits \& Cost Studies 2nd Edition.” Rocky Mountain Institute. https://rmi.org/wpcontent/uploads/2017/05/RMI_Document_Repository_Public-Reprts_eLab-DER-Benefit-CostDeck_2nd_Edition131015.pdf.

Kurtz, S. and M. Bolen. 2016. "Retaining the Value of PV at High Penetration Workshop." NREL/PR-5J00-67467. Golden, CO: National Renewable Energy Laboratory. https://www.nrel.gov/docs/fy17osti/67467.pdf.

Lazar, J. 2016. "Value of Solar and Grid Benefits Studies: Alternative Approaches and Results." The Regulatory Assistance Project. http://www.raponline.org/knowledge-center/value-solar-gridbenefits-studies-alternative-approaches-results/.

Mills, A. and R. Wiser. 2012. “An Evaluation of Solar Valuation Methods Used in Utility Planning and Procurement Processes." Lawrence Berkeley National Laboratory. https://emp.lbl.gov/sites/all/files/lbnl-5933e.pdf.

Taylor, M., J. McLaren, K. Cory, T. Davidovich, J. Sterling, and M. Makhyoun. 2015. "Value of Solar: Program Design and Implementation Considerations." NREL/TP-6A20-62361. Golden, CO: National Renewable Energy Laboratory. http:/www.nrel.gov/docs/fy15osti/62361.pdf.

The Electric Power Research Institute (EPRI). 2015. The Integrated Grid: A Benefit-Cost Framework. Palo Alto, CA. https:/www.epri.com/\#/pages/product/000000003002004878/. 


\section{A.2 Next Generation Considerations: Distributed Solar Plus Storage}

O'Shaughnessy, E., K. Ardani, D. Cutler, and R. Margolis. 2017. Solar Plus: A Holistic Approach to Distributed Solar PV. NREL/TP-6A20-68371. Golden, CO: National Renewable Energy Laboratory. http://www.nrel.gov/docs/fy17osti/68371.pdf.

- Presentation: https://www.nrel.gov/docs/fy17osti/68495.pdf

- Fact Sheet: https://www.nrel.gov/docs/gen/fy17/68497.pdf

\section{A.3 Market Case Studies}

Gagnon, P., and B. Sigrin. 2015. "Distributed PV Adoption in Maine Through 2021." NREL/PR6A20-66204. Golden, CO: National Renewable Energy Laboratory. http://www.nrel.gov/docs/fy16osti/66204.pdf. Gagnon, P., B. Sigrin, and M. Gleason. 2017. "The Impacts of Changes to Nevada's Net Metering Policy on the Financial Performance and Adoption of Distributed Photovoltaics." NREL/TP-6A20-66765. Golden, CO: National Renewable Energy Laboratory. http://www.nrel.gov/docs/fy17osti/66765.pdf.

Gagnon, P. and P. Das. 2017. "Projections of Distributed Photovoltaic Adoption in Kentucky through 2040." NREL/PR-6A20-68656. Golden, CO: National Renewable Energy Laboratory. http://www.nrel.gov/docs/fy17osti/68656.pdf.

Jorgenson, J., P. Denholm, and M. Mehos. 2014. "Estimating the Value of Utility-Scale Solar Technologies in California Under a 40\% Renewable Portfolio Standard." NREL/TP-6A2061685. Golden, CO: National Renewable Energy Laboratory. https://www.nrel.gov/docs/fy17osti/67467.pdf.

Ong, S. 2012. "White Paper: The Value of Grid-Connected Photovoltaics in Michigan." Golden, CO: National Renewable Energy Laboratory. http://www.michigan.gov/documents/mpsc/120123_PVvaluation_MI_394661_7.pdf.

\section{A.4 Other Resources}

Keyes, J. and K. Rábago. 2013. "A Regulator's Guidebook: Calculating the Benefits and Costs of Distributed Solar Generation." Interstate Renewable Energy Council, Inc. http://www.irecusa.org/publications/a-regulators-guidebook-calculating-the-benefits-and-costsof-distributed-solar-generation/.

Linvill, C., J. Shenot, J., and J. Lazar. 2013. "Designing Distributed Generation Tariffs Well: Fair Compensation in a Time of Transition." The Regulatory Assistance Project. http://www.raponline.org/wp-content/uploads/2016/05/rap-linvillshenotlazar-faircompensation2013-nov-27.pdf.

Migden-Ostrander, J. and J. Shenot. 2016. "Designing Tariffs for Distributed Generation Customers." The Regulatory Assistance Project. http://www.raponline.org/wpcontent/uploads/2016/05/rap-madri-designingtariffsfordgcustomers-final.pdf.

Woo, C.K. and J. Zarnikau. 2017. "A solar rate option for the development of behind-the-meter photovoltaic systems." The Electricity Journal.

https://www.sciencedirect.com/science/article/pii/S1040619017300520. 